IZA DP No. 5078

Wages, Employment and Tenure of Temporarily Subsidized Workers: Does the Industry Matter?

Gesine Stephan

July 2010 


\title{
Wages, Employment and Tenure of Temporarily Subsidized Workers: Does the Industry Matter?
}

\author{
Gesine Stephan \\ Institute for Employment Research (IAB), \\ University of Erlangen-Nuremberg and IZA
}

\author{
Discussion Paper No. 5078 \\ July 2010
}

IZA

P.O. Box 7240

53072 Bonn

Germany

Phone: +49-228-3894-0

Fax: +49-228-3894-180

E-mail: iza@iza.org

Any opinions expressed here are those of the author(s) and not those of IZA. Research published in this series may include views on policy, but the institute itself takes no institutional policy positions.

The Institute for the Study of Labor (IZA) in Bonn is a local and virtual international research center and a place of communication between science, politics and business. IZA is an independent nonprofit organization supported by Deutsche Post Foundation. The center is associated with the University of Bonn and offers a stimulating research environment through its international network, workshops and conferences, data service, project support, research visits and doctoral program. IZA engages in (i) original and internationally competitive research in all fields of labor economics, (ii) development of policy concepts, and (iii) dissemination of research results and concepts to the interested public.

IZA Discussion Papers often represent preliminary work and are circulated to encourage discussion. Citation of such a paper should account for its provisional character. A revised version may be available directly from the author. 
IZA Discussion Paper No. 5078

July 2010

\section{ABSTRACT \\ Wages, Employment and Tenure of Temporarily Subsidized Workers: Does the Industry Matter?*}

This paper explores whether wage, employment and tenure outcomes of workers taking up a job subsidized by the German Federal Employment Agency differ by industry. The analysis utilizes administrative data and statistical matching techniques; it covers an observation period of 3.5 years. First, we conduct a within-industry comparison of temporarily subsidized and otherwise similar unsubsidized workers. The findings show for most industries that subsidized workers had similar short-run wages, but fared significantly better in the longer run. Second, we compare labor market outcomes of subsidized workers within each industry with those of similar subsidized workers in other industries. The main result is that cumulated wages of workers would not have differed significantly, if they had been hired in another industry instead. However, we find significant differences in short-term wages, employment and tenure outcomes across industries. Finally, from a fiscal point of view it seems more advantageous to subsidize workers hired in industries that are less subject to demand fluctuations.

JEL Classification: J31, J38, J58

Keywords: wage subsidies, industry-specific effects, program evaluation

Corresponding author:

Gesine Stephan

Institute for Employment Research (IAB)

Regensburger Str. 104

90478 Nuremberg

Germany

E-mail: gesine.stephan@iab.de

\footnotetext{
* I am grateful to Elke Jahn, Anton Nivorozhkin and Torben Schewe for helpful comments, to the SWA2 unit of the German Public Employment Service - in particular Michael Irskens - as well as to the ITM unit of the Institute for Employment Research for providing the data.
} 


\section{Introduction}

Wage subsidies reduce labor costs and thus provide an incentive for employers to hire workers whose factual or perceived productivity does not cover their labor costs (Bell et al. 1999). In Germany, caseworkers in local labor market offices may grant such wage subsidies to employers, if these hire workers with temporarily productivity deficits at a particular job. If firms dismiss workers during the subsidization period or a follow-up period of the same length, they can be obliged to reimburse part of the subsidy. Thus, workers have the opportunity during this "protection period" to increase productivity through learning-on-the-job and to reduce an employer's uncertainty about their skills. Such wage subsidies are an important part of German active labor market policies: From 2003 to 2005 , the number of entries into the program decreased from 180,000 to 134,000 , but afterwards it increased again to around 250,000 yearly entries during 2007 to 2009 .

Notwithstanding the high number of entries into such programs, the recent literature on wage subsidies does not provide much information whether effects on the employment prospects of subsidized workers vary by industry. This study aims to fill this gap in the literature. For job entries during the second quarter of 2003, it explores whether wage, employment and tenure outcomes of subsidized and unsubsidized workers differ across ten German industries, in which 70 percent of all subsidized workers were hired. In a first step, we compare labor market outcomes of individuals taking up a subsidized job with those of similar unsubsidized hires within the same industry. In a second step, we ask whether a worker taking up a subsidized job in a particular sector would have benefited from finding a subsidized job in another sector. The analysis is based on administrative data; comparisons groups are selected by means of statistical matching.

Several studies have already investigated the effect of wage subsidies on the employment and tenure outcomes of subsidized workers in the US, Sweden, Belgium, the UK and Germany (e.g. Burtless 1985, Card/Hyslop 2009, Carling/Richardson 2004, Cockx et al. 1998, Dorsett 2006, Fredriksson/Johansson 2008, Forslund et al. 2004, Göbel 2006, 2007, Jaenichen 2002, Jaenichen/Stephan 2009, Ruppe 2009, Sianesi 2008), or on the wages of initially subsidized workers (Dubin/Rivers 1993, Brouillette/Lacroix 2008, Hamersma 2008). This paper extends and builds on a previous study for Germany (Ste- 
phan 2010), which did, however, not differentiate between industries. For the short-run, it showed that wages of previously unemployed workers taking up a subsidized job did not differ from those of otherwise similar individuals who found an unsubsidized job. Thus, in contrast to previous studies for the US, neither evidence on rent sharing through subsidies (Hamersma 2008) nor stigma effects of subsidies (Dubin/Rivers 1993, Brouillette/Lacroix 2008) were found. But cumulated wages of subsidized workers were higher over a longer time-horizon, because their employment shares exceeded those of unsubsidized workers.

With few exceptions, however, firm heterogeneity in selection into schemes as well as in determining these outcomes has been neglected in the literature. For the US Work Opportunity Tax Credit and the Welfare-to-Work Tax Credit programs, Hamersma (2010) analyzed why only a fraction of employers of eligible workers claimed subsidies and found that firms with a larger fraction of workers exceeding the program's job duration thresholds are more likely to claim the subsidy. For the same programs, Hamersma/Heinrich (2008) paid particular attention to subsidies granted to temporary help firms. They showed that subsidized workers in the analyzed US temporary help firms had higher earnings than unsubsidized ones; nonetheless, their earnings and tenure were lower than those of subsidized workers in other industries.

The broad international literature on inter-industry wage differentials (starting with Dickens/Katz 1987, Krueger/Summers 1987, 1988) has shown that large and persistent inter-industry wage differences prevail even after controlling for a variety of worker and job related characteristics as well as for unobserved worker heterogeneity. Such differentials may reflect sectoral differences in the human capital endowment of the workforce, non-pecuniary aspects of work, rent-sharing opportunities, or the institutional setting (see for instance the discussion in Genre et al. 2009). Fitzenberger/Kurz (2003) provided an overview on earlier studies of inter-industry wage differentials in Germany. Recent work for Germany has paid particular attention to the temporary help sector: For 2004, Jahn (2010) found that temporary help firm workers received only 55 percent of wage of workers in other industries, and that a gap of around 20 percent remained controlling for observable and unobservable individual characteristics.

Regarding selection of subsidized workers into particular industries, one might expect that the importance of subsidies in combination with a "protection period" may be 
smaller in industries that are characterized by strong seasonal fluctuations of employment and where labor demand is difficult to predict. Furthermore, subsidies may be particularly well suited for industries where learning on the job enhances productivity considerably or where settling-in costs are comparatively low. However, our main focus of interest is not on the inter-industry wage structure as such or on selection processes into industries, but on wage and employment outcomes of subsidized workers. In this context, it is sensible to assume that as soon as a temporarily subsidized employment relationship has taken place, it may be shielded by some extent against firms' adjustments in employment. Thus, workers taking up a job within industries that are subject to frequent adjustments (seasonal or business-cycle related) may profit particularly from the "protection period" associated with subsidies. This does not rule out, however, that they would have fared even better, if they would have found a subsidized job within another industry with less employment fluctuations.

Our study shows that results on the effectiveness of subsidies within particular industries depend on the particular question asked; in other words, findings from an intraindustry and an inter-industry comparison do not necessarily coincide: Within most industries and in the longer run, this paper finds that - in terms of cumulated wages, employment prospects as well as tenure within the hiring firm - workers that were hired with the help of a subsidy fare significantly better than similar workers taking up an unsubsidized job. Effects on cumulated wages over our observation period of 3.5 years are particularly high in the construction industry and hotels and restaurants, which are characterized by strong seasonal adjustments in employment. However, an interindustry comparison of subsidized workers shows that cumulated wages of subsidized workers would not have differed significantly, if they had been hired in another industry instead. Nonetheless, from a fiscal point of view, it seems more advantageous to grant subsidies for workers hired in industries that are less subject to demand fluctuations.

In the following, Section 2 briefly describes the program and the data set, while Section 3 depicts the econometric strategy and the variables used. Section 4 discusses withinindustry results and Section 5 inter-industry estimates. Finally, Section 6 summarizes and draws some conclusions. 


\section{Program features and data set}

This study jointly analyzes entries into two similar wage subsidy schemes for employers that were in place in Germany during the period between 1998 and 2003 (and were merged during 2004). One type provided compensation for special training requirements ("Eingliederungszuschuss bei Einarbeitung") and could be granted for up to 30 percent of monthly wages for up to 6 months. The other type was aimed at hard-to-place unemployed with severe problems of reintegration ("Eingliederungszuschuss bei erschwerter Vermittlung"); it could account for as much as 50 percent of the monthly salary and continue for at most 12 months. Within the legal framework, caseworkers in local employment agencies had latitude in the allowance decision as well as in the fixing of the amount and duration of the subsidy. Subsidies could not be granted, if the worker had previously been regularly employed at the firm applying for the subsidy during the last four years.

An important feature of the subsidy is the "protection period" associated with it: If the employer dismissed (for reasons attributable to the firm) a subsidized person within the subsidization period or a follow-up period of the same length, the employer could be asked to reimburse part of the subsidy. In line with these regulations, Hartmann (2004) found survey evidence that firms restrained from hiring because of flexibility requirements and if they could not predict labor demand in the longer run. As has already been noted, Hamersma (2010) showed for the US that in particular firms with a larger fraction of workers exceeding the program's job duration thresholds were likely to claim employment subsidies.

When determining the size of the subsidy, only wages up to the collectively negotiated or the local customary level, respectively, and up to social security thresholds can be taken into account. Furthermore, there seems to be an informal consensus that subsidies should not support wage dumping and that the subsidized wages should not be below the local customary wage level (ZEW et al. 2006). Stephan (2010) points out that the high importance of collective agreements in Germany implies that lower or higher wages for subsidized workers than for unsubsidized workers within similar jobs and within the same firm might first not be feasible (if the firm is covered by a collective agreement and the worker is unionized) and, second and even more importantly, be as- 
sessed as not acceptable or unfair, respectively, by workers, firms' management and also by caseworkers.

Our analysis is based on an administrative data set of the German Federal Employment Agency, the Treatment Effects and Prediction data (TrEffeR) (Stephan et al. 2006). The data combine data flows on periods of registered job search, registered unemployment, participation in labor market programs and employment. ${ }^{1}$ Information on the characteristics of the job - in particular on wages - is merged from the employment history files $(\mathrm{BeH})$ of the Institute for Employment Research (IAB). These are based on notifications of employment to the social security insurance and thus entail an upper bound on the wage information at the social security contribution limits. As we will see, however, subsidized employment is generally low wage employment, thus our analysis is not affected by this restriction. Daily wages are computed by dividing entire earnings during an employment spell by the duration of the spell in days (including days without work). Regrettably, the data do not provide information on planned durations of subsidization, exact weekly working hours, whether an employer applies a collective contract, on the individual caseworker involved and on mean job tenure within firms.

The sample used here covers all individuals who entered full-time employment during the second quarter of 2003 after a period of unemployment of up to one year. Subsequent wages and employment of workers are observed over a period of 3.5 years. The analysis restricts itself to individuals aged 25 to 49 at the beginning of their unemployment spell (younger and older persons might be eligible for specific programs for their age groups) and to individuals who had not had an employment spell within the same firm during the past three years. Excepting the first subsidized employment spell, our main focus is on times in unsubsidized employment that were subject to social insurance contributions. Thus, when computing cumulated wage and employment outcomes, we exclude all marginal employment spells and spells with a daily wage rate of less than 10 Euro from our analysis as well as further periods of subsidized employment. If parallel employment spells were observed, we take into account only the spell with the

1 The TrEffeR data set is not available for public use, but it is composed of the same data flows as the Integrated Employment Biographies (IEB) of the Institute for Employment Research (Hummel et al. 2005), for which a research data set is available. 
highest daily wage rate. For computing job tenure, we assume that an individual is employed within the same firm as long as the firm identifier in social security notifications remains the same (see Brixy/Fritsch 2002 for further information on this topic).

For all industries, the remaining data set contains around 10,000 entries in subsidized and 180,000 entries into unsubsidized employment. Our analysis restricts itself on those 10 out of 61 industries where we observe at least 400 entries (or 4 percent of all entries, respectively) in subsidized jobs. These sectors cover around 7,000 entries in subsidized and 125,000 entries in unsubsidized employment. The industry classification we use is the WZ03 ("Wirtschaftszweigklassifikation 2003") at the two-digit-level; as an exception, we classify temporary help firms (that are coded at the five-digit-level and belong to economic services) as an own industry. ${ }^{2}$ Important parts of the remaining "other economic services" are in particular cleaning and security services.

Table 1: $\quad$ Sectoral composition of entries into employment (in percent)

\begin{tabular}{|c|c|c|c|c|c|}
\hline & $\begin{array}{r}\text { Across } \\
\text { Subsidized }\end{array}$ & $\begin{array}{l}\text { ctors } \\
\text { Unsub- } \\
\text { sidized }\end{array}$ & $\begin{array}{l}\text { Within sector } \\
\text { Subsidized }\end{array}$ & $\begin{array}{l}\text { Subsidized } \\
\text { Training } \\
\text { subsidy } \\
\end{array}$ & $\begin{array}{c}\text { within sector } \\
\text { Hard-to-place } \\
\text { subsidy }\end{array}$ \\
\hline Metal products & 4.6 & 2.6 & 8.9 & 62.8 & 37.2 \\
\hline Construction & 19.5 & 23.5 & 4.4 & 61.6 & 38.4 \\
\hline Automobile trade/repair & 4.0 & 1.7 & 12.0 & 54.2 & 45.8 \\
\hline Wholesale & 5.8 & 4.1 & 7.4 & 55.5 & 44.5 \\
\hline Retail trade & 6.6 & 4.5 & 7.6 & 46.9 & 53.1 \\
\hline Hotels/restaurants & 4.5 & 6.9 & 3.5 & 41.9 & 58.1 \\
\hline Land transportation & 4.0 & 2.9 & 7.1 & 47.5 & 52.5 \\
\hline Temporary help firms & 6.2 & 12.3 & 2.8 & 28.4 & 71.6 \\
\hline Other economic services & 9.5 & 6.7 & 7.3 & 53.0 & 47.0 \\
\hline Health/social services & 4.5 & 4.3 & 5.5 & 53.7 & 46.3 \\
\hline Other 51 industries & 30.9 & 30.5 & 5.4 & 56.1 & 43.9 \\
\hline Total & 100.0 & 100.0 & 5.3 & 53.6 & 46.4 \\
\hline
\end{tabular}

Note: Previously unemployed workers taking up a full-time job during the second quarter of 2003.

Table 1 shows the sectoral composition of the data set in percentages, including those sectors not investigated further. While less than 4 percent of all entries in unsubsidized employment occurred in two of the selected industries (automobile trade and repair as

2 Some studies interpret employment in a temporary help firm itself as a treatment itself and investigate the stepping stone effect of temporary help work into regular jobs (e.g. Jahn/Rosholm 2010). 
well as land transportation), only one of the sectors excluded from our analysis covers around 4 percent of all entries (agriculture). As Table 1 shows, most hires by far occurred within the construction sector. This is certainly driven by seasonal factors as we analyze entries from spring 2003. The highest share of subsidized entries is found in automobile trade and repair, where a subsidy was granted for more than 12 percent of new hires. While both types of the subsidy - for training purposes and for hard-to-place individuals - included in our investigation account for roughly half of all subsidized hires, we find some variation across sectors: In particular, within temporary help firms around 70 percent of subsidies were granted for hard-to-place unemployed persons.

\section{$3 \quad$ Method and variables}

Let us denote workers taking up a subsidized job during the second quarter of 2003 in a particular industry as the "treatment group". The outcome variables we analyze are 1) nominal short-run wages (daily wages when taking up the job), 2) nominal cumulated wages over the entire observation period of 3.5 years (assuming wages of zero during times without employment), 3) cumulated days of employment over the entire observation period, and 4) job tenure in the first employment relationship during this period in days.

For different industries, we are first interested in the mean difference in outcome variables between the treatment group and otherwise comparable workers, who started an unsubsidized job during the same time period. Second, we ask for the difference in outcomes between the treatment group and otherwise comparable workers, who started a subsidized employment relationship within one of the other industries under consideration. We apply "matching on observables" to find adequate comparison groups (Rubin 1974). The identifying assumption is that accounting for observable differences across individuals in the treatment and the comparison group - no unobserved heterogeneity correlated with the selection into programs and with outcome variables remains. In other words, we assume that all variables $\mathrm{X}$, determining these participation decisions as well as the expected success of taking up subsidized employment in a particular sector are known and available. Then the mean outcome in the comparison group estimates the mean unobserved outcome that members of the treatment group would have had, if they 
would not have been supported by a subsidy (in this particular sector). With nonexperimental data, regression and duration analysis might be applied, too. Matching, however, makes no functional form assumptions and avoids an identification of effects from projections into regions where there are no data points.

Because of the high number of observable variables we have to take into account, we conduct a matching on the propensity score - the probability to join a program - to obtain the same probability distribution for treated and non-treated individuals (Rosenbaum and Rubin 1983). First, we estimate the individual probability to be subsidized the propensity score - by a binary probit. Second, we select a comparison such that the distributions of the propensity scores are similar for both groups of workers. For this purpose, we conduct a radius matching (Dehejia/Wahba 2002), which matches the treatment group with "synthetic" comparison persons, composed of a weighted equivalent of all persons falling within the radius of their propensity score. The estimates were performed using the stata module psmatch2 (Leuven/Sianesi 2003). We choose a radius or caliper - the maximum distance of propensity scores between treated and comparison persons - of 0.002. Note that results are very stable, regardless of the particular matching algorithm or caliper chosen. Finally, we compute differences of outcome variables between the treatment and comparison groups. We will additionally present graphs on shares over time for both outcome variables, because employment shares vary over time and the job tenure variable is right censured.

With statistical matching, a counterfactual can be found only for those individuals in the treatment group who are in common support with individuals in the potential comparison group (see for instance Caliendo/Kopenig 2008). Common support ensures that persons with the same $\mathrm{X}$ values - and thus the same propensity scores - have a positive probability of being both participants and non-participants. Individuals whose propensity scores are outside the region of common support have to be disregarded from the analysis. We delete all observations whose propensity score is larger than the maximum and smaller than the minimum in the opposite group as well as those for whom no counterpart is found within the defined caliper. Of course, this implies that estimated effects are only consistent for the subpopulation within common support.

For a causal interpretation of our matching results, the method requires us to observe all variables that are relevant a) for the assignment process into subsidized employment 
within a particular sector (compared to finding an unsubsidized job or a subsidized job in another industry, respectively) and b) for subsequent labor market outcomes. In fact, the data underlying our analysis encompass a comprehensive number of variables at the individual, firm and regional level that should be critical for selection as well as for outcomes. Table 2 presents an overview on the variables underlying the estimates, which are mostly categorized as dummy variables. Note in particular that we account for productivity differences between individuals by taking into account percentiles of the latest daily wage and cumulated wages before taking up the job under consideration (percentiles are computed across the 10 industries in our final data set). Furthermore, we control in a rather detailed way for the last occupation before the unemployment spell.

Table 2: $\quad$ Variables used for the propensity score matching

\begin{tabular}{|c|c|}
\hline Variable group & Variables \\
\hline $\begin{array}{l}\text { i) Individual socio- } \\
\text { demographic } \\
\text { characteristics }\end{array}$ & $\begin{array}{l}\text { Measured at the beginning of the unemployment spell: Gender, living } \\
\text { in East- or West-Germany, marital status, nationality, age group, } \\
\text { health problems, disability, attained degree of schooling and educa- } \\
\text { tion, recipient of unemployment benefits or assistance. }\end{array}$ \\
\hline $\begin{array}{l}\text { ii) Individual labor market } \\
\text { history }\end{array}$ & $\begin{array}{l}\text { Participation in an active labor market program during the unemploy- } \\
\text { ment spell (five categories) } \\
\text { Measured since the start of the unemployment spell: Duration until } \\
\text { taking up the job } \\
\text { Measured at the start of the unemployment spell: Days in employment } \\
\text { (last three years) and days in unemployment (last two years), participa- } \\
\text { tion in labor market programs (last two years), sanctioned through } \\
\text { caseworker (last two years) and periods of sickness (last two years) }\end{array}$ \\
\hline iii) Last occupation & Occupation in last job before unemployment (27 categories) \\
\hline iv) Firm and job characteristics & $\begin{array}{l}\text { Firm size class, sectoral affiliation, mean daily wage in firm (four } \\
\text { categories), blue or white collar job }\end{array}$ \\
\hline $\begin{array}{l}\text { v) Local labor market } \\
\text { characteristics }\end{array}$ & Performance cluster of the regional labor market (Blien et al. 2004) \\
\hline vi) Previous wages & $\begin{array}{l}\text { Percentiles of latest daily wage and previous cumulated wages during } \\
\text { the last three years (ten categories each) }\end{array}$ \\
\hline
\end{tabular}

Table A.1 in the Appendix presents mean values of the variables considered, before the matching took place, and we will describe shortly the most obvious differences between subsidized and unsubsidized workers as well as between industries: i) Beginning with socio-demographics, workers supported by a subsidy were over-proportionally EastGerman men, had better education and received unemployment assistance. Hires in 
most industries are male-dominated (exceptions are hotels and restaurants and health and social services) and occur predominantly in West-Germany. Human capital endowment seems to be comparatively low for hires in hotels and restaurants as well as in temporary help firms. ii) Regarding the individual labor market history, those who took up a subsidized job had participated more often in another labor market program during their current as well as previous unemployment spells. ${ }^{3}$ During the years preceding their unemployment spell, they have spent less time in employment and more time in unemployment. Comparing hires across industries, workers in the manufacturing of metal products as well as in automobile trade and repairs seem to be most attached to the labor market. iii) The last occupation individuals were working in before their unemployment spell mirrors to a certain extent also selection into actual industries. For instance, around one third of workers hired in the metal products industry had been working as a mechanic in his or her last job. iv) Selectivity seems to persist (beneath sectoral affiliation) on the firm's side. Subsidized employment is utilized over-proportionally by small firms and low-wage firms. Furthermore, strong differences between sectors are found: The share of hires by large firms is highest in the temporary help sector, where also wages - lower than in hotels and restaurants - are rather low. Regarding job characteristics, it is noteworthy that the share of unqualified blue collar workers exceeds 50 percent within temporary help firms. v) Subsidized employment relationships are found comparatively more often in East German regions. In the period under investigation, in particular the construction sector hired comparatively much individuals in East German regions with a bad labor market situation. vi) Those taking up a subsidized job had on average lower earnings during the 3 years preceding their current unemployment spell. Across sectors, previous wages were particularly low for workers hired in health and social services.

3 In several cases, hiring subsidized as well as unsubsidized workers is directly preceded by a shortterm training measure within a firm. While information on the firm where the training took place is missing in the data, it is sensible to assume that it took place within the same firm. Consequently, the dummy variable for firm-internal training has been coded to zero, if such a training program took place directly within the month before taking up the job, because it can be regarded as part of the job already. 
Additionally, Table A.1 provides some information on the duration and size of the subsidies granted: The mean actual duration of subsidization in the 10 industries amounted to 4 to 5 months. We do not have individual information on the size of the subsidy, but information merged through cost accounting at the local level indicates that the average daily subsidy amounted to 17 to 20 Euros, with average costs of subsidization around 2,400 to 3,000 Euros, depending on the particular industry. The duration of the subsidy was actually lowest in the temporary help sector, while the average daily subsidy rate was highest.

While our approach takes into account comprehensive information about individual, job related and regional characteristics, several restrictions apply: First, we ignore that the subsidy might have been essential for the hiring decision, but we assume that differences in labor market outcomes across subsidized and unsubsidized workers are related to the subsidy or the "protection period" associated with the subsidy. Thus, our study underestimates the effects on labor market outcomes of unemployed individuals, but estimates the effect for newly hired persons. Second, although our analysis controls for a number of important individual and firm related features, we cannot entirely rule out that further (unobserved) selection processes took place. In particular, our inter-industry comparison assumes that subsidized workers would have been able to take up a subsidized job within another industry, too. Our analysis takes this into account, however, as far as possible by controlling for the last occupation before entering unemployment. It is not adequate to control for actual occupation as this will be to some extent determined by the firm or industry someone is working in: In fact, the last row in Table A.1 shows that more than 40 percent of all individuals in our sample switched occupations when taking up their new job; and the share was even around 50 percent for subsidized workers. Third, the analysis restricts itself to the estimation of direct effects of the subsidy on participating workers and does not take into account possible indirect effects on nonparticipants. However, an analysis of displacement and substitution as well as effects on reservation wages would require a macro-analysis on the regional level.

Finally, as an addition to the matching analysis, we conduct a simple fiscal cost-benefitanalysis of direct program effects for subsidized workers along the lines suggested in Stephan (2010). This enables us to get a very rough impression of the efficiency of the subsidy: The computations rely on the validity of the assumptions outlined above, and 
the analysis does not take into account possible indirect effects like substitution and displacement of previously unsubsidized workers through previously subsidized workers. As has already been mentioned subsidy rates are not available on an individual base, but estimated from cost accounting at the local level. Savings in unemployment benefit and unemployment assistance are computed from individual daily rates received at the beginning of the unemployment spell. Employer and employee social security contributions and taxes are assumed to account for on average 50 percent of additional incomes (see also Pfeiffer/Winterhager 2005).

\section{Comparisons of subsidized and unsubsidized workers within industries}

Table 3 presents the main results of our comparison of workers taking up subsidized or unsubsidized jobs, respectively, within the same industry. Subsidized work is on average low-wage employment. The German low-wage threshold for 2003, defined as twothirds of the median wage rate of all employment relationships, amounted to 59 Euro in West and 42 Euro per day in East Germany (Rhein/Stamm 2006). Within our data set, in the short-run, subsidized mean wages were - with around 38 Euros per day - lowest in hotels and restaurants. They were highest in the construction sector, where subsidized workers received daily wages of about 58 Euros. Thus, our results display well known inter-industry wages differentials (e.g. Genre et al. 2009).

Before matching (rows B), the mean daily wage when taking up the job as well as cumulated wages over a period of 3.5 year were found to be significantly lower for subsidized workers within most industries investigated. The largest differences are shown for health and social services, with 14.7 Euro less per day and 13,200 Euro less over a period of 3.5 years for subsidized workers. The only exception is the temporary help sector where mean wages of newly hired subsidized workers did not differ from those of all other hires. Average days in employment as well as job tenure within the first firm were, however, mostly higher for subsidized workers even in the unmatched sample. The penultimate row in Table A. 1 shows the share of workers switching the industry at least once during the observation period: In line with longer mean job tenure, it is generally much lower across subsidized workers than across unsubsidized ones. 
Table 3: $\quad$ Mean labor market outcomes for workers taking up a subsidized (S) or unsubsidized $(\mathrm{U})$ job within the same industry and differences $(\Delta)$ across both groups before (B) and after (A) matching

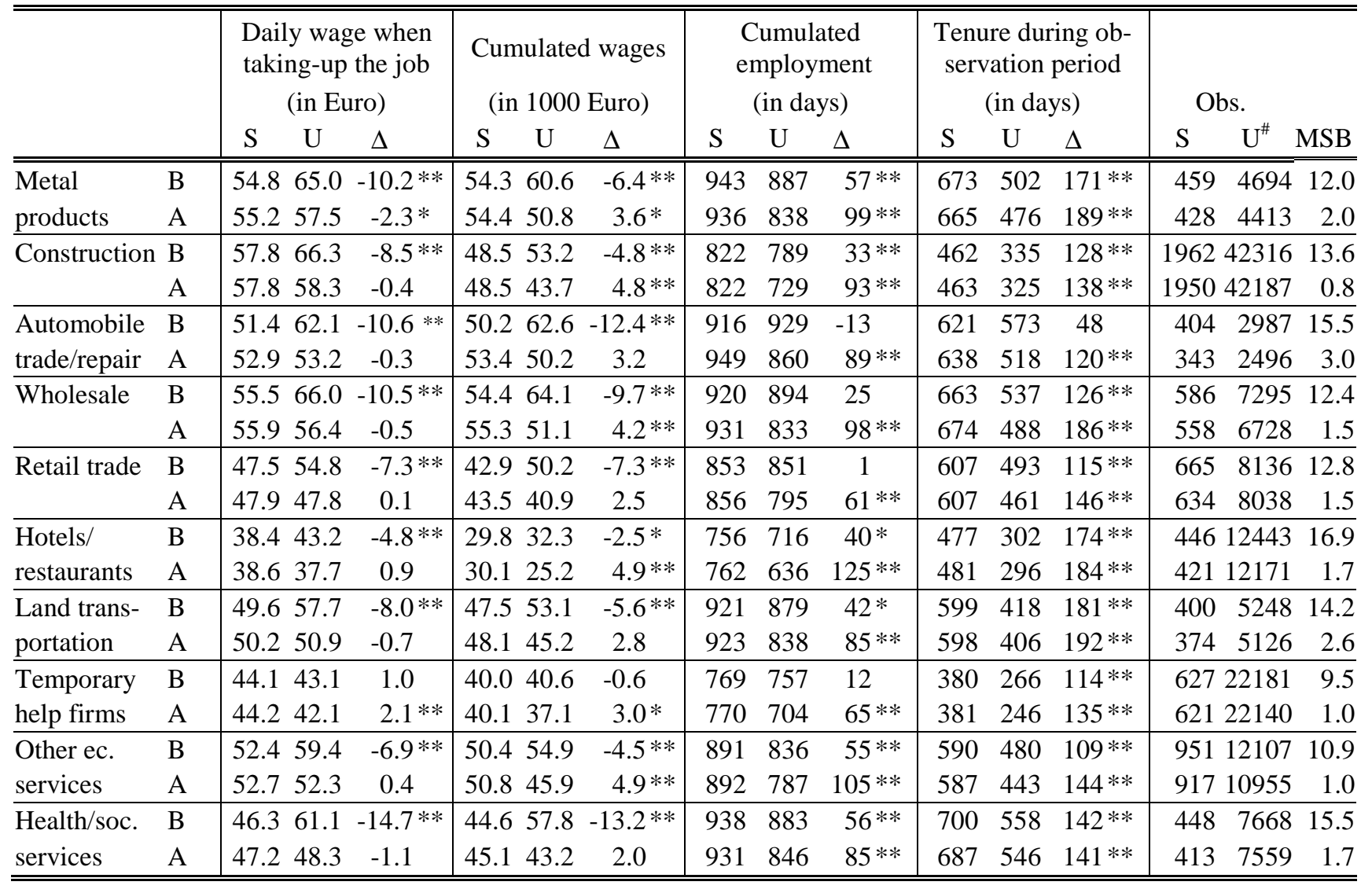

*) Significant at $\alpha=0.05$. **) Significant at $\alpha=0.01$.

\#) Displays the unweighted number of observations after matching.

Results after matching can be found in rows A of Table 3. The mean standardized bias (MSB, given in the last rows of Table 3) between the two groups of workers decreases considerably through matching, indicating a very good matching quality for all industries investigated. It is obvious that differences in daily wages found before matching were to a large extent due to differences in observed characteristics. Furthermore, we lose in average 6 percent of participants due to common support requirements, which seems acceptable. 4

4 Table 3 displays the unweighted number of comparison group observations underlying the estimates; the weighted number of comparison persons after matching is consistent with the number of treated persons. 
Figure 1: $\quad$ Shares in employment for workers taking up a subsidized job and matched unsubsidized comparison persons within the same industry as well as difference in shares

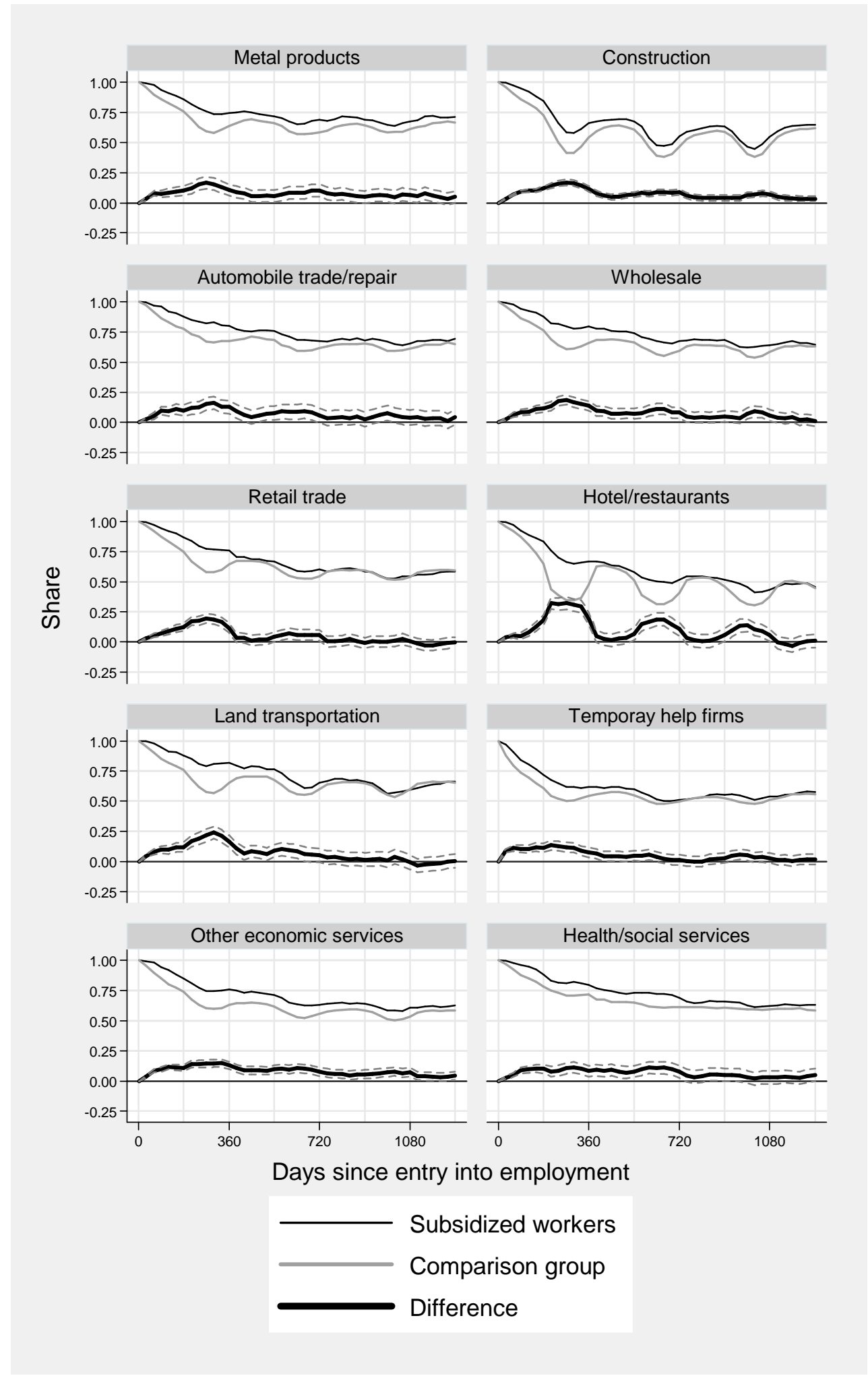

Note: Confidence intervals for the difference in shares are given for $\alpha=0.05$. 
Figure 2: $\quad$ Shares in first job (survivor function) for workers taking up a subsidized job and matched unsubsidized comparison persons within the same industry as well as difference in shares
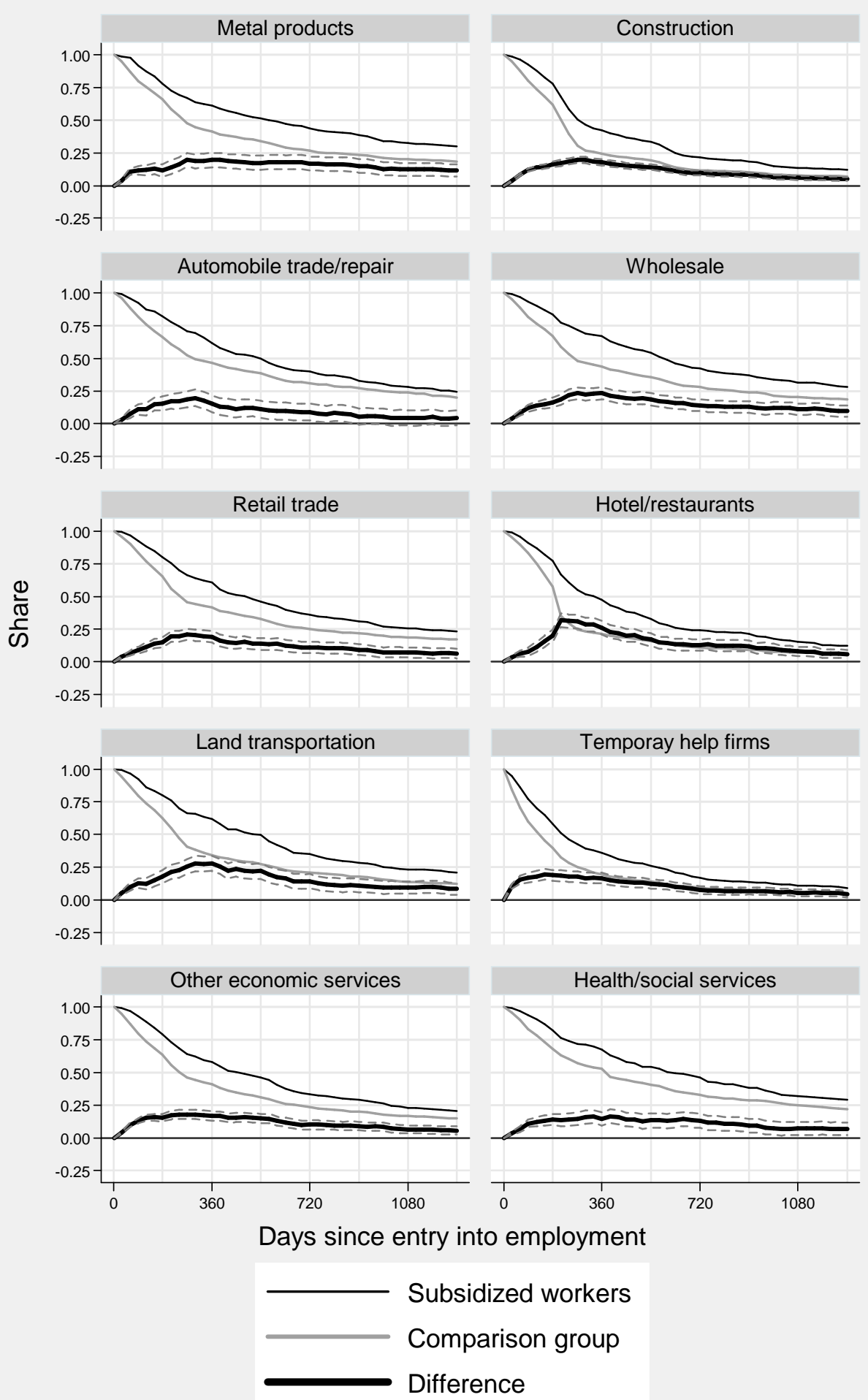

Note: Confidence intervals for the difference in shares are given for $\alpha=0.05$. 
After matching, wage differences decline considerably and remain significant only for two sectors: Subsidized workers in firms manufacturing metal products received slightly lower wages than similar unsubsidized workers, while the opposite was true for hires in temporary help firms. Cumulated wages across 3.5 years were, however, higher for subsidized workers than for their unsubsidized counterparts in 6 out of 10 industries. The longer-term advantage of workers hired with the help of a subsidy is most obvious in hotels and restaurants and in other economic services, where cumulated earnings were about 4,900 Euros higher. Insignificant differences are found only for the metal products industry, automobile trade and repair as well as in health and social services.

Furthermore, we see clearly that previously subsidized workers spent significantly more days in employment in the first firm than their unsubsidized counterparts. Effects on job tenure are much higher than effects on days in employment. Additional days in employment sum up from around 2 months (temporary help agencies) to around 4 months (hotels and restaurants), and mean job tenure at the first employer is longer by 4 months (automobile trade and repair, temporary help agencies) to more than 6 months (metal products, wholesale, hotels and restaurants, land transportation).

Figures 1 and 2 provide further information on the evolvement of shares in employment and job tenure within the first firm (survivor function) over time. The integrals below shares and differences equal cumulated outcomes and their difference, respectively, in Table 3. Figure 1 shows that previously subsidized workers seem to be less subject to seasonal adjustments - even within the same industries. This is most obvious for the hotel and restaurant branch. Figure 2 highlights that subsidized employment relationships are more stable than unsubsidized ones in particular during the first months of an employment relationship (see also Ruppe 2009). Differences in survivor functions peak between 6 to 12 months after taking up the relevant job. The aforementioned "protection period" might be an important reason for longer job durations of previously subsidized workers. Nonetheless, we cannot preclude the possibility that firms hire subsidized workers in particular in jobs that are characterized by on average longer job tenure, thus selection may still play a role on the firm's side. For new employment relationships in Germany taken up between 1996 and 2001, Boockmann/Steffes (2010) found that more than 50 percent of these ended during the first two years. Among our subgroup of pre- 
viously unemployed persons that were hired without the help of a subsidy, jobs were much more unstable within most industries.

Results of the simple fiscal cost-benefit analysis are presented in Table A.2 in the Appendix. While the findings should be interpreted with care, they indicate for most industries that wage subsidies might be self-financing over the longer run: The fiscal net effect is in most cases not significantly different from zero. The highest fiscal gain of nearly (and significant) 1,800 Euro is found for the construction industry, where subsidized workers profit from comparatively high sectoral wages. Even though cumulated employment effects in this industry are moderate in comparison to other sectors, they translate into comparatively high cumulated earnings and thus taxes and social security contributions. Of course, this does not imply that results for subsidized workers in other industries - whose characteristics differ from those of subsidized workers in construction - would have been similar, if they would have started to work in construction instead. This will be shown within the next section.

\section{Comparisons for subsidized workers across industries}

In the next step, we compare individuals taking up subsidized employment within one industry with workers taking up a subsidized job in one of the other 9 sectors under consideration. Table 4 presents the main results.

Results before matching - and thus not accounting for observed characteristics - are displayed in rows B. Mirroring to a certain extent the results from Table 3, we find a clear ranking of wages of subsidized workers' wages, with highest daily wages in construction (around 9 Euro higher than the average across other industries) and lowest daily wages in hotels and restaurants (around 14 Euros lower than the average across other industries). This translates only partly into cumulated wages over a period of 3.5 years as these are determined by cumulated days in employment, too: Compared to other branches, cumulated wages were up to around 8,200 Euros higher for workers in wholesale and up to around 18,300 Euro lower in hotels and restaurants. Furthermore, we find remarkable differences in cumulated days in employment, which were for instance around 4 months lower for subsidized workers in hotels and restaurants or in temporary help firms. Mean job tenure within the first firm was comparatively low in 
temporary help firms - workers who took up a subsidized job in other sectors stayed within the same firm around six more months.

Table 4: $\quad$ Mean labor market outcomes for workers taking up a subsidized job within a particular industry $(\mathrm{S})$ or within the other 9 industries $(\mathrm{O})$ and differences across both groups $(\Delta)$ before (B) and after (A) matching

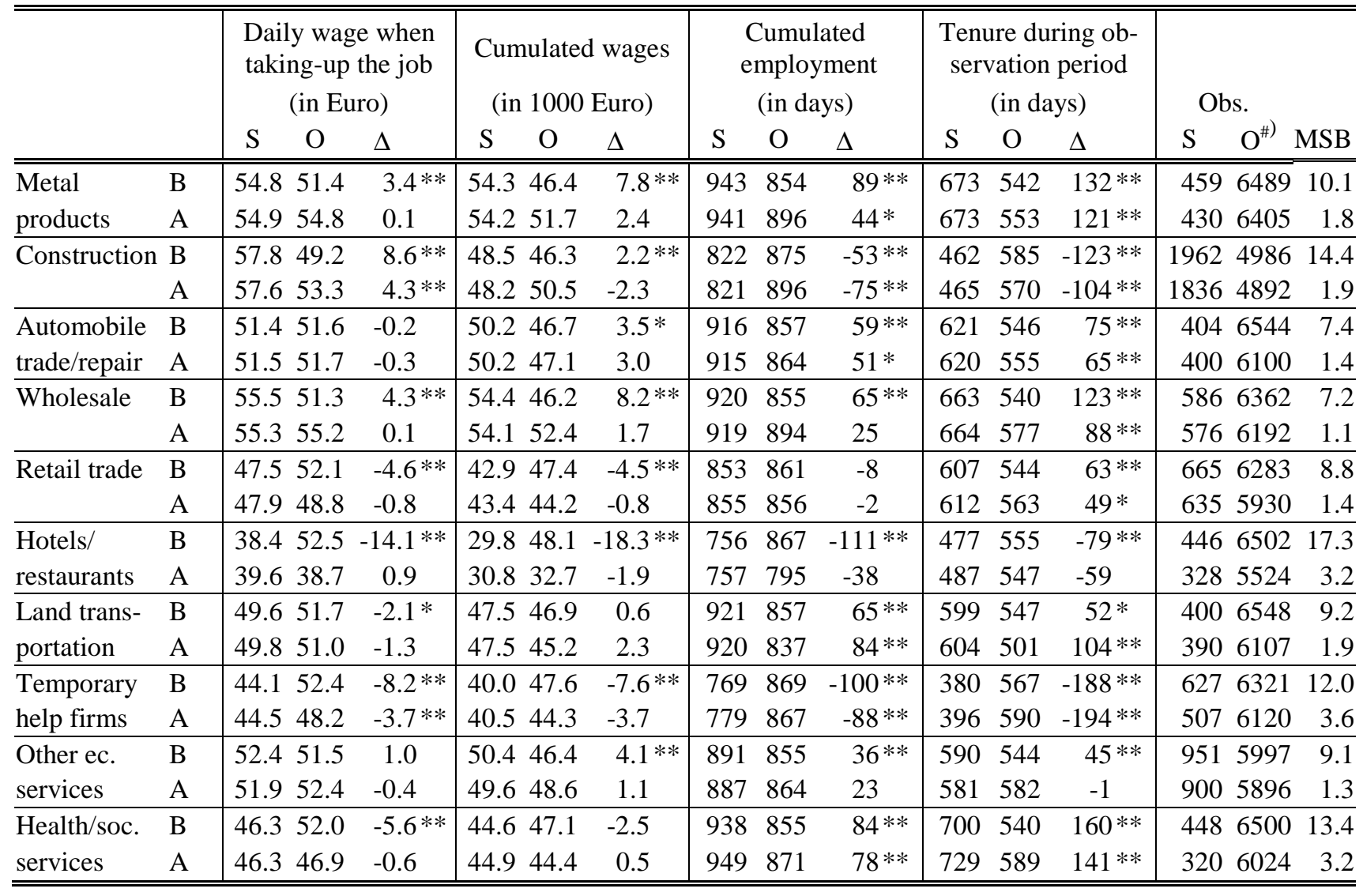

*) Significant at $\alpha=0.05$. **) Significant at $\alpha=0.01$.

${ }^{\#)}$ Displays the unweighted number of observations after matching.

In a next step, we select comparison groups - comprised of otherwise similar workers in similar firms and regions - from the pool of individuals taking up a job in one of the other 9 industries. Table A.3 shows the sectoral composition of the comparison group chosen. As could have been expected, comparison persons for individuals working in services stem mostly from other service industries, while those for individuals working in metal products manufacturing are often working in construction, vice versa. Results after matching are displayed in rows $\mathrm{A}$ in Table 4. Again, the mean standardized bias (MSB) indicates a very good quality of matching. Due to common support requirements, on average 10 percent of participants are excluded from the estimates. The share 
of "lost observations" is highest in hotels and restaurants and in health and social services where it reaches 20 to 30 percent.

Controlling for observed differences in characteristics, estimated differences between treatment and control group mostly decrease. Most important, we find no longer any significant differences in cumulated wages of temporarily subsidized workers across industries. Cumulated wages are, however, determined by daily wages as well as by employment times, and here we find in fact differences across industries. First, daily wages in subsidized employment relationships in construction (temporary help firms) were around 4 Euros higher (lower) than in similar subsidized jobs within other sectors. Second, in particular subsidized workers within construction and temporary help firms spent significantly less time in employment than similar subsidized individuals taking up a job in another sector. The pattern is mirrored by mean duration of job tenure at the first employer, which is more than 6 months lower for subsidized workers within the temporary help sector, and around 3 months lower for workers, who took up a subsidized job in construction, than for comparable subsidized workers, who found a job within another industry.

Finally, Table A.4 estimates the fiscal costs and benefits of granting a subsidy in a particular industry, compared to doing so for similar workers within one of the other industries. We assume that the costs of the subsidy would have been the same, if employment would have been taken up in another industry. Table A.4 shows that from a fiscal point of view, benefits would have been significantly larger, if workers taking up subsidized jobs in construction and temporary help firms (which are subject to rather strong demand fluctuations) would have been able to find a subsidized job within another industry. The underlying reason is that - even if cumulated wages would have been the same in other industries - days in employment have a higher fiscal effect (through savings in unemployment benefits) than higher daily wages (through additional taxes and social security contributions). No significant net effects are found for the other industries.

It seems rather surprising that Table A.4 displays a negative balance for construction, where cumulated wages of subsidized workers were comparatively high when conducting a comparison with similar unsubsidized workers (Section 4, Table A.2). Compared to other subsidized workers, those in construction are, however, over-proportionally male East German qualified blue collar workers with comparatively high past wages. 
While their subsequent employment shares were higher than those of unsubsidized workers within the same branch, employment shares of similar subsidized workers within other industries were even higher (by around 3 months).

\section{Summary and conclusions}

For Germany, this paper estimates industry-specific effects of a wage subsidy program that granted time-limited supplements to firms that hired hard-to-place workers or hired workers into jobs with particular training requirements. First, we ask how subsequent wages and employment outcomes differ between similar workers, who took up a subsidized or unsubsidized job, respectively, within a particular industry. Second, we compare outcomes of subsidized workers across different industries. The analyzed sample covers workers taking up a job during the second quarter of 2003 and observes wage and employment outcomes over a period of 3.5 years. We use a large process generated data set, providing information on individual, regional and firm characteristics as well as on previous wages. Adequate comparison groups for subsidized workers within a particular industry are selected by means of statistical matching.

As a first main result of the study, we find that subsidized workers within most sectors earn no significantly different wages in the short-run, realize higher cumulated earnings in the long-run, spend more days in employment, and stay significantly longer at their first employer than similar unsubsidized workers. The size of the effects differs, however, across sectors. Additional cumulated earnings range from 2,000 Euro (health and social services, insignificant) to 4,800 Euros (hotels and restaurants, significant). Differences in employment and tenure outcomes vary from 2 and 4 months (temporary help firms) to 4 and 6 months (hotels and restaurants).

As a second main result of the study, we find that cumulated wages of initially subsidized workers did not differ across industries over a longer period. We find, however, several significant inter-industry differences regarding employment and tenure outcomes of temporarily subsidized workers: Job tenure is shorter by several months for subsidized workers taking up a job in sectors that are characterized by seasonal fluctuations (construction) or uncertain demand conditions (temporary help firms). 
A fiscal cost-benefit analysis based on the results from the latter estimates indicates that society may profit mostly from subsidizing jobs in sectors that are not subject to varying demand conditions. Considering the fact, however, that a rather high share of all hires out of unemployment takes place within these sectors, the potential for alternatives may be low. Furthermore, subsidized workers even within these industries initially fare better than similar workers taking up an unsubsidized job. The "protection period", encompassing the subsidization period and an obligatory follow-up period of the same length, is obviously often of sufficient length for workers to increase their productivity through learning-on-the-job and to reduce uncertainties about their skills.

Finally, we would like to point out that a causal interpretation of our results relies on the assumption that we observe all variables that are relevant for taking part in the subsidy program when taking up a job as well as for subsequent labor market outcomes. In fact, we control for a comprehensive set of variables that should pick up much of the individual, job-related and regional heterogeneity across workers. However, particularly when comparing subsidized workers across industries, it might be questionable whether a worker would in fact have been able to switch industries. Furthermore, our study is restricted to program entries during the second quarter of 2003. The effectiveness of subsidies may be subject to seasonal and business cycle conditions during the time when the relevant job was taken up. Finally, the institutional setting for several branches has been modified since 2003. An industry-specific minimum wage has been introduced in construction (König/Möller 2009). Since the end of 2003, temporary help firms have to pay their workers the wage paid by the client firm; alternatively, temporary help firms could join an industry level collective agreement (Jahn 2010). Thus, an interesting line for future research would be to analyze entries in subsidized work for a longer period of calendar time in particular for those two industries.

\section{References}

Bell, B., Blundell, R., Van Reenen, J. (1999): Getting the Unemployed Back to Work: The Role of Targeted Wage Subsidies, International Tax and Public Finance 6, 339-360.

Blien, U., Hirschenauer, F., Arendt, M., Braun, H.-J.; Gunst, D.-M., Kilcioglu, S., Kleinschmidt, H., Musati, M., Roß, H., Vollkommer, D., Wein, J. (2004): Typisierung von Bezirken der Agenturen für Arbeit, Zeitschrift für Arbeitsmarktforschung 37, 146-175. 
Boockmann, B, Steffes, S. (2010, forthcoming): Workers, Firms or Institutions: What Determines Job Duration for Male Employees in Germany?, Industrial and Labor Relations Review.

Brixy, U., Fritsch, M. (2002): Die Betriebsdatei der Beschäftigtenstatistik der Bundesanstalt für Arbeit, in: Fritsch, M., Grotz, R. (eds.): Das Gründungsgeschehen in Deutschland. Darstellung und Vergleich der Datenquellen, Heidelberg, 55-78.

Brouillette, D., Lacroix, G. (2008): Heterogeneous Treatment and Self-Selection in a Wage Subsidy Experiment, IZA Discussion Paper 3738.

Burtless, G. (1985): Are Targeted Wage Subsidies Harmful? Evidence from a Wage Voucher Experiment, Industrial and Labor Relations Review 39, 105-114.

Caliendo, M., Kopeinig, S. (2008): Some practical guidance for the implementation of propensity score matching, Journal of Economic Surveys 22, 31-72.

Card, D., Hyslop, D.R. (2009): The Dynamic Effects of an Earnings Subsidy for Long-term Welfare Recipients: Evidence from the Self Sufficiency Project Applicant Experiment, Journal of Econometrics 153, 1-20.

Carling, K., Richardson, K. (2004): The Relative Efficiency of Labour Market Programs: Swedish Experience from the 1990s, Labour Economics 11, 335-354.

Cockx, B., Van der Linden, B., Karaa, A. (1998): Active Labour Market Policies and Job Tenure, Oxford Economic Papers 10, 685-708.

Dehejia, R. H., Wahba, S. (2002): Propensity score matching methods for nonexperimental causal studies, The Review of Economics and Statistics, 84, 151-161.

Dickens, W.T., Katz, L.F. (1987): Inter-Industry Wage Differences and Industry Characteristics, in: Lang, K., Leonard, J.S. (eds.), Unemployment and the Structure of Labor Markets, Basil Blackwell, Oxford, 48-89.

Dorsett, R. (2006): The New Deal for Young People: Effects on the Labour Market Status of Young Men, Labour Economics 13, 405-422.

Dubin, J.A., Rivers, D. (1993): Experimental Estimates of the Impact of Wage Subsidies, Journal of Econometrics 53, 219-242.

Fitzenberger, G., Kurz, C. (2003): New Insights on Earnings Trends Across Skill Groups and Industries in West Germany, Empirical Economics 28, 479-514.

Forslund, A., Johansson, P., Lindqvist. L. (2004): Employment Subsidies - A Fast Lane From Unemployment to Work?, IFAU Working Paper 2004:18.

Fredriksson, P., Johansson, P. (2008): Dynamic Treatment Assignment - The Consequences for Evaluations Using Observational Data, Journal of Business and Economic Statistics 26, 435-445.

Genre, V., Kohn, K., Momferatou, D. (2009): Understanding Inter-Industry Wage Structures in the Euro Area, IZA Discussion Paper 4114.

Göbel, C. (2006): The Effect of Temporary Employment Subsidies on Employment Duration, Départment des Sciences Économiques de l'Université catolique de Louvain Discussion Paper 2006-35.

Göbel, C. (2007): The Effect of Participation in Subsidised Employment on Labour Market Tranistitions, mimeo.

Hamersma, S. (2008): The Effects of an Employer Subsidy on Employment Outcomes. A Study of the Work Opportunity and Welfare-to-work Tax Credits, The Journal of Policy Analysis and Management 27, 498-520..

Hamersma, S. (2010, forthcoming): Why Don't Eligible Firms Claim Hiring Subsidies? The Role of Job Duration, Economic Inquiry. 
Hamersma, S., Heinrich, C. (2008): Temporary Help Service Firm's Use of Employer Tax Credits: Implications for Disadvantaged Workers' Labor Market Outcomes, Institute for Research on Poverty Discussion Paper 1335-08.

Hartmann, J. (2004): Lohnkostenzuschüsse und Integration schwer vermittelbarer Personen in den ersten Arbeitsmarkt, Beiträge zur Arbeitsmarkt- und Berufsforschung 284, Nürnberg.

Hummel, E., Jacobebbinghaus, P., Kohlmann, A., Oertel, M., Wübbeke, C., Ziegerer, M. (2005): Stichprobe der Integrierten Erwerbsbiografien IEBS 1.0, FDZ-Datenreport 6/2005.

Jaenichen, U. (2002): Lohnkostenzuschüsse und individuelle Arbeitslosigkeit, Mitteilungen aus der Arbeitsmarkt- und Berufsforschung 35, 327-351.

Jaenichen, U., Stephan, G. (2009): The Effectiveness of Targeted Wage Subsidies for Hard-toPlace Workers, Applied Economics, doi:10.1080/00036840802600426 (online first)

Jahn, E. (2010): Reassessing the Pay Gap for Temps in Germany, Jahrbücher für Nationalökonomie und Statistik 230, 208-233.

Jahn, E., Rosholm, M. (2010): Looking beyond the bridge: How temporary agency employment affects labor market outcomes, IAB Discussion Paper 09/2010.

König, M., Möller, J. (2009): Impacts of minimum wages - a microdata analysis for the German construction sector, International Journal of Manpower 30, 716-741.

Krueger, A.B., Summers, L.H. (1987): Reflections on the Inter-Industry Wage Structure, in: Lang, K., Leonard, J.S. (eds.), Unemployment and the Structure of Labor Markets, Basil Blackwell, Oxford, 17-47.

Krueger, A.B., Summers, L.H. (1988): Efficiency Wages and the Inter-Industry Wage Structure, Econometrica 56, 259-293.

Leuven, E., Sianesi, B. (2003): psmatch2: Stata module to perform full Mahalanobis and propensity score matching, common support graphing, and covariate imbalance testing, http://ideas.repec.org/c/boc/bocode/s432001.html.

Pfeiffer, F., Winterhager, H. (2005): Vermittlungsgutscheine: Zwischenergebnisse der Begleitforschung 2004, Teil V, Kosten-Nutzen-Analyse, IAB Forschungsbericht 5/2005.

Rhein, T., Stamm, M. (2006): Niedriglohnbeschäftigung in Deutschland - Deskriptive Befunde zur Entwicklung seit 1980 und Verteilung auf Berufe und Wirtschaftszweige, IABForschungsbericht 12/2006.

Rosenbaum, P.R., Rubin, D.B. (1983): The Central Role of the Propensity Score in Observational Studies for Causal Effects, Biometrika 70, 41-55.

Rubin, D.B. (1974): Estimating Causal Effects of Treatments in Randomized and Nonrandomized Studies, Journal of Educational Psychology 66, 688-701.

Ruppe, K. (2009): Eingliederungszuschüsse und Betriebszugehörigkeit in Westdeutschland, Institute for Employment Research, Nuremberg, IAB Discussion Paper 6/2009.

Sianesi, B. (2008): Differential Effects of Active Labour Market Programs for the Unemployed, Labour Economics 15, 392-421.

Stephan, G., Rässler, S., Schewe, T. (2006): Das TrEffeR-Projekt der Bundesagentur für Arbeit: Die Wirkung von Maßnahmen aktiver Arbeitsmarktpolitik, Zeitschrift für Arbeitsmarktforschung 39, 447-466.

Stephan, G. (2010): Employer wage subsidies and wages in Germany: empirical evidence from individual data, Zeitschrift für ArbeitsmarktForschung 43, 53-71

ZEW, IAB, IAT (2006): Evaluation der Maßnahmen zur Umsetzung der Vorschläge der HartzKommission. Arbeitspaket 1: Wirksamkeit der Instrumente, Modul 1d: Eingliederungszuschüsse und Entgeltsicherung, Final Report to the Federal Ministry of Labor. 


\section{Appendix}

Table A.1: Dummy variable means for workers taking up a subsidized (S) or unsubsidized (U) job within the same industry before matching

\begin{tabular}{|c|c|c|c|c|c|c|c|c|c|c|c|c|c|c|c|c|c|c|c|c|c|}
\hline & & \multicolumn{2}{|c|}{$\begin{array}{c}\text { Metal } \\
\text { products }\end{array}$} & \multicolumn{2}{|c|}{ Construction } & \multicolumn{2}{|c|}{$\begin{array}{l}\text { Automobile } \\
\text { trade/repair }\end{array}$} & \multicolumn{2}{|c|}{ Wholesale } & \multicolumn{2}{|c|}{ Retail trade } & \multicolumn{2}{|c|}{$\begin{array}{l}\text { Hotels/ } \\
\text { restaurants }\end{array}$} & \multicolumn{2}{|c|}{$\begin{array}{c}\text { Land } \\
\text { transportation }\end{array}$} & \multicolumn{2}{|c|}{$\begin{array}{l}\text { Temporary } \\
\text { help firms }\end{array}$} & \multicolumn{2}{|c|}{$\begin{array}{l}\text { Other ec. } \\
\text { services }\end{array}$} & \multicolumn{2}{|c|}{$\begin{array}{l}\text { Health/soc. } \\
\text { services }\end{array}$} \\
\hline & & $\mathrm{S}$ & $\mathrm{U}$ & $\mathrm{S}$ & $\mathrm{U}$ & $\mathrm{S}$ & $\mathrm{U}$ & $\mathrm{S}$ & $\mathrm{U}$ & $\mathrm{S}$ & $\mathrm{U}$ & $\mathrm{S}$ & $\mathrm{U}$ & $\mathrm{S}$ & $\mathrm{U}$ & $\mathrm{S}$ & $\mathrm{U}$ & $\mathrm{S}$ & $\mathrm{U}$ & $\mathrm{S}$ & $\mathrm{U}$ \\
\hline \multirow{23}{*}{ 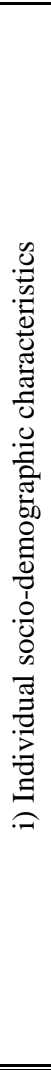 } & Male, West Germany & 0.35 & 0.62 & 0.28 & 0.59 & 0.39 & 0.64 & 0.38 & 0.60 & 0.32 & 0.41 & 0.15 & 0.35 & 0.38 & 0.63 & 0.52 & 0.55 & 0.31 & 0.45 & 0.15 & 0.24 \\
\hline & Female, West Germany & 0.05 & 0.08 & 0.03 & 0.02 & 0.06 & 0.15 & 0.13 & 0.21 & 0.19 & 0.36 & 0.14 & 0.31 & 0.04 & 0.05 & 0.14 & 0.18 & 0.16 & 0.28 & 0.32 & 0.58 \\
\hline & Male, East Germany & 0.51 & 0.27 & 0.65 & 0.37 & 0.43 & 0.16 & 0.37 & 0.16 & 0.19 & 0.11 & 0.21 & 0.10 & 0.54 & 0.30 & 0.27 & 0.24 & 0.32 & 0.18 & 0.08 & 0.04 \\
\hline & $\underline{\text { Female, East Germany }}$ & 0.09 & 0.03 & 0.04 & 0.01 & 0.13 & 0.05 & 0.12 & 0.04 & 0.31 & 0.12 & 0.50 & 0.24 & 0.05 & 0.02 & 0.07 & 0.04 & 0.21 & 0.09 & 0.45 & 0.13 \\
\hline & Married & 0.54 & 0.54 & 0.52 & 0.55 & 0.44 & 0.47 & 0.55 & 0.50 & 0.48 & 0.46 & 0.43 & 0.45 & 0.51 & 0.52 & 0.36 & 0.42 & 0.47 & 0.43 & 0.50 & 0.41 \\
\hline & Foreigner & 0.06 & 0.12 & 0.05 & 0.09 & 0.07 & 0.09 & 0.06 & 0.10 & 0.06 & 0.08 & 0.09 & 0.20 & 0.06 & 0.08 & 0.09 & 0.13 & 0.05 & 0.11 & 0.03 & 0.07 \\
\hline & Age $25-29$ & 0.15 & 0.21 & 0.21 & 0.21 & 0.31 & 0.27 & 0.20 & 0.22 & 0.20 & 0.24 & 0.25 & 0.22 & 0.19 & 0.16 & 0.24 & 0.27 & 0.20 & 0.25 & 0.19 & 0.25 \\
\hline & Age $30-34$ & 0.24 & 0.22 & 0.19 & 0.22 & 0.22 & 0.24 & 0.20 & 0.23 & 0.21 & 0.23 & 0.21 & 0.21 & 0.22 & 0.22 & 0.24 & 0.20 & 0.23 & 0.23 & 0.19 & 0.21 \\
\hline & Age $35-39$ & 0.23 & 0.21 & 0.22 & 0.23 & 0.17 & 0.21 & 0.24 & 0.23 & 0.23 & 0.22 & 0.21 & 0.22 & 0.23 & 0.21 & 0.20 & 0.20 & 0.21 & 0.21 & 0.27 & 0.21 \\
\hline & Age $40-44$ & 0.21 & 0.21 & 0.22 & 0.20 & 0.18 & 0.16 & 0.21 & 0.19 & 0.20 & 0.18 & 0.20 & 0.20 & 0.22 & 0.22 & 0.19 & 0.19 & 0.20 & 0.18 & 0.18 & 0.20 \\
\hline & Age 45-49 & 0.17 & 0.14 & 0.16 & 0.14 & 0.12 & 0.12 & 0.15 & 0.13 & 0.16 & 0.13 & 0.13 & 0.16 & 0.14 & 0.19 & 0.13 & 0.14 & 0.16 & 0.13 & 0.16 & 0.14 \\
\hline & Health problems & 0.06 & 0.05 & 0.03 & 0.03 & 0.05 & 0.05 & 0.04 & 0.05 & 0.06 & 0.05 & 0.07 & 0.04 & 0.08 & 0.06 & 0.05 & 0.05 & 0.05 & 0.05 & 0.05 & 0.06 \\
\hline & $\underline{\text { Severely disabled }}$ & 0.03 & 0.02 & 0.01 & 0.01 & 0.01 & 0.02 & 0.01 & 0.02 & 0.02 & 0.03 & 0.02 & 0.02 & 0.01 & 0.02 & 0.02 & 0.02 & 0.02 & 0.02 & 0.02 & 0.03 \\
\hline & No secondary degree & 0.06 & 0.08 & 0.06 & 0.09 & 0.05 & 0.05 & 0.05 & 0.07 & 0.04 & 0.05 & 0.08 & 0.11 & 0.05 & 0.08 & 0.10 & 0.11 & 0.04 & 0.08 & 0.03 & 0.03 \\
\hline & Secondary degree (Hauptschule) & 0.36 & 0.48 & 0.34 & 0.52 & 0.31 & 0.46 & 0.28 & 0.42 & 0.31 & 0.42 & 0.28 & 0.41 & 0.42 & 0.54 & 0.41 & 0.46 & 0.27 & 0.33 & 0.22 & 0.28 \\
\hline & Secondary degree (Realschule) & 0.50 & 0.35 & 0.55 & 0.36 & 0.55 & 0.39 & 0.52 & 0.35 & 0.54 & 0.40 & 0.59 & 0.41 & 0.48 & 0.33 & 0.39 & 0.34 & 0.45 & 0.35 & 0.60 & 0.41 \\
\hline & $\underline{\text { Secondary degree (Gymnasium) }}$ & 0.08 & 0.08 & 0.05 & 0.03 & 0.08 & 0.10 & 0.15 & 0.16 & 0.11 & 0.13 & 0.05 & 0.07 & 0.06 & 0.04 & 0.11 & 0.10 & 0.24 & 0.24 & 0.15 & 0.27 \\
\hline & No vocational training & 0.15 & 0.23 & 0.13 & 0.18 & 0.13 & 0.15 & 0.16 & 0.21 & 0.14 & 0.18 & 0.20 & 0.31 & 0.20 & 0.26 & 0.26 & 0.30 & 0.14 & 0.22 & 0.12 & 0.14 \\
\hline & Vocational training & 0.81 & 0.74 & 0.85 & 0.80 & 0.84 & 0.82 & 0.79 & 0.73 & 0.84 & 0.78 & 0.79 & 0.68 & 0.79 & 0.72 & 0.70 & 0.67 & 0.74 & 0.65 & 0.84 & 0.73 \\
\hline & University degree & 0.04 & 0.03 & 0.02 & 0.01 & 0.03 & 0.03 & 0.05 & 0.06 & 0.03 & 0.04 & 0.01 & 0.01 & 0.01 & 0.02 & 0.04 & 0.03 & 0.12 & 0.13 & 0.04 & 0.13 \\
\hline & Unemployment benefits receipt & 0.59 & 0.73 & 0.61 & 0.76 & 0.58 & 0.75 & 0.56 & 0.73 & 0.55 & 0.73 & 0.42 & 0.72 & 0.54 & 0.71 & 0.48 & 0.60 & 0.53 & 0.68 & 0.55 & 0.67 \\
\hline & Unemployment assistance receipt & 0.16 & 0.07 & 0.18 & 0.06 & 0.22 & 0.06 & 0.18 & 0.07 & 0.23 & 0.07 & 0.34 & 0.09 & 0.24 & 0.07 & 0.25 & 0.11 & 0.22 & 0.09 & 0.19 & 0.07 \\
\hline & No benefit receipt & 0.25 & 0.20 & 0.21 & 0.17 & 0.20 & 0.20 & 0.25 & 0.20 & 0.22 & 0.20 & 0.24 & 0.20 & 0.23 & 0.22 & 0.27 & 0.29 & 0.25 & 0.23 & 0.25 & 0.26 \\
\hline
\end{tabular}




\begin{tabular}{|c|c|c|c|c|c|c|c|c|c|c|c|c|c|c|c|c|c|c|c|c|c|}
\hline & & \multicolumn{2}{|c|}{$\begin{array}{l}\text { Metal } \\
\text { products }\end{array}$} & \multicolumn{2}{|c|}{ Construction } & \multicolumn{2}{|c|}{$\begin{array}{l}\text { Automobile } \\
\text { trade/repair }\end{array}$} & \multicolumn{2}{|c|}{ Wholesale } & \multicolumn{2}{|c|}{ Retail trade } & \multicolumn{2}{|c|}{$\begin{array}{l}\text { Hotels/ } \\
\text { restaurants }\end{array}$} & \multicolumn{2}{|c|}{$\begin{array}{c}\text { Land } \\
\text { transportation }\end{array}$} & \multicolumn{2}{|c|}{$\begin{array}{l}\text { Temporary } \\
\text { help firms }\end{array}$} & \multicolumn{2}{|c|}{$\begin{array}{l}\text { Other ec. } \\
\text { services }\end{array}$} & \multicolumn{2}{|c|}{$\begin{array}{l}\text { Health/soc. } \\
\text { services }\end{array}$} \\
\hline & & S & $\mathrm{U}$ & $\mathrm{S}$ & $\mathrm{U}$ & $\mathrm{S}$ & $\mathrm{U}$ & $\mathrm{S}$ & $\mathrm{U}$ & $\mathrm{S}$ & $\mathrm{U}$ & $\mathrm{S}$ & $\mathrm{U}$ & $\mathrm{S}$ & $\mathrm{U}$ & $\mathrm{S}$ & $\mathrm{U}$ & $\mathrm{S}$ & $\mathrm{U}$ & $\mathrm{S}$ & $\mathrm{U}$ \\
\hline \multirow{25}{*}{ 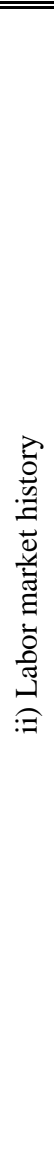 } & "During current $\mathrm{UE}^{\#}$. : Wage subsidy & 0.02 & 0.00 & 0.02 & 0.00 & 0.01 & 0.00 & 0.02 & 0.00 & 0.03 & 0.00 & 0.02 & 0.00 & 0.02 & 0.00 & 0.02 & 0.00 & 0.01 & 0.00 & 0.02 & 0.00 \\
\hline & During current UE.: Further vocational training & 0.07 & 0.02 & 0.03 & 0.00 & 0.02 & 0.00 & 0.03 & 0.01 & 0.03 & 0.01 & 0.02 & 0.01 & 0.03 & 0.01 & 0.04 & 0.02 & 0.04 & 0.01 & 0.02 & 0.01 \\
\hline & During current UE.: Short training within firm & 0.06 & 0.09 & 0.05 & 0.04 & 0.05 & 0.09 & 0.05 & 0.06 & 0.06 & 0.06 & 0.06 & 0.02 & 0.06 & 0.07 & 0.05 & 0.03 & 0.05 & 0.07 & 0.04 & 0.04 \\
\hline & During current UE: Short classroom training & 0.16 & 0.08 & 0.11 & 0.04 & 0.13 & 0.07 & 0.15 & 0.08 & 0.15 & 0.07 & 0.15 & 0.05 & 0.09 & 0.05 & 0.13 & 0.08 & 0.13 & 0.08 & 0.15 & 0.06 \\
\hline & During current UE.: Other program & 0.02 & 0.00 & 0.01 & 0.00 & 0.02 & 0.00 & 0.02 & 0.00 & 0.02 & 0.00 & 0.02 & 0.00 & 0.02 & 0.00 & 0.03 & 0.01 & 0.01 & 0.00 & 0.01 & 0.01 \\
\hline & Job entry during month 1 of UE & 0.08 & 0.10 & 0.06 & 0.05 & 0.06 & 0.13 & 0.06 & 0.11 & 0.07 & 0.11 & 0.06 & 0.08 & 0.06 & 0.10 & 0.06 & 0.12 & 0.07 & 0.11 & 0.08 & 0.19 \\
\hline & Job entry during month $2-3$ of UE & 0.17 & 0.24 & 0.14 & 0.15 & 0.19 & 0.26 & 0.15 & 0.22 & 0.14 & 0.23 & 0.14 & 0.17 & 0.14 & 0.21 & 0.13 & 0.24 & 0.16 & 0.23 & 0.21 & 0.31 \\
\hline & Job entry during month 4-6 of UE & 0.32 & 0.40 & 0.38 & 0.59 & 0.29 & 0.33 & 0.32 & 0.37 & 0.31 & 0.36 & 0.27 & 0.41 & 0.29 & 0.45 & 0.27 & 0.33 & 0.31 & 0.35 & 0.25 & 0.26 \\
\hline & Job entry during month 7-9 of UE & 0.23 & 0.18 & 0.25 & 0.16 & 0.26 & 0.18 & 0.25 & 0.18 & 0.22 & 0.19 & 0.28 & 0.27 & 0.32 & 0.16 & 0.27 & 0.20 & 0.23 & 0.19 & 0.27 & 0.14 \\
\hline & Job entry during month $10-12$ of UE & 0.20 & 0.08 & 0.17 & 0.05 & 0.20 & 0.10 & 0.23 & 0.11 & 0.26 & 0.11 & 0.24 & 0.07 & 0.19 & 0.08 & 0.28 & 0.12 & 0.23 & 0.12 & 0.19 & 0.09 \\
\hline & 3 years before UE: Employed up to 1 month & 0.12 & 0.04 & 0.07 & 0.02 & 0.12 & 0.05 & 0.10 & 0.05 & 0.15 & 0.06 & 0.18 & 0.05 & 0.11 & 0.03 & 0.14 & 0.07 & 0.15 & 0.08 & 0.25 & 0.14 \\
\hline & 3 years before UE: Employed 1-6 months & 0.07 & 0.04 & 0.05 & 0.02 & 0.07 & 0.04 & 0.07 & 0.04 & 0.09 & 0.04 & 0.13 & 0.04 & 0.08 & 0.03 & 0.13 & 0.06 & 0.09 & 0.05 & 0.07 & 0.05 \\
\hline & 3 years before UE: Employed 7-12 months & 0.08 & 0.05 & 0.10 & 0.05 & 0.14 & 0.05 & 0.11 & 0.07 & 0.09 & 0.07 & 0.17 & 0.09 & 0.11 & 0.07 & 0.14 & 0.10 & 0.13 & 0.08 & 0.11 & 0.08 \\
\hline & 3 years before UE: Employed 13-18 months & 0.15 & 0.11 & 0.18 & 0.10 & 0.14 & 0.09 & 0.13 & 0.11 & 0.18 & 0.11 & 0.19 & 0.16 & 0.17 & 0.12 & 0.22 & 0.15 & 0.16 & 0.13 & 0.16 & 0.11 \\
\hline & 3 years before UE: Employed 19-24 months & 0.12 & 0.14 & 0.19 & 0.21 & 0.15 & 0.14 & 0.14 & 0.14 & 0.15 & 0.15 & 0.11 & 0.26 & 0.17 & 0.18 & 0.14 & 0.17 & 0.12 & 0.15 & 0.09 & 0.12 \\
\hline & 3 years before UE: Employed 25-30 months & 0.22 & 0.24 & 0.24 & 0.33 & 0.19 & 0.24 & 0.25 & 0.24 & 0.17 & 0.24 & 0.15 & 0.22 & 0.20 & 0.28 & 0.17 & 0.22 & 0.20 & 0.23 & 0.19 & 0.18 \\
\hline & 3 years before UE: Employed 30-36 months & 0.25 & 0.38 & 0.18 & 0.26 & 0.19 & 0.39 & 0.19 & 0.36 & 0.16 & 0.34 & 0.07 & 0.19 & 0.18 & 0.29 & 0.06 & 0.22 & 0.15 & 0.28 & 0.14 & 0.32 \\
\hline & 2 years before UE: Unemployed up to 1 month & 0.52 & 0.58 & 0.35 & 0.35 & 0.41 & 0.64 & 0.47 & 0.60 & 0.44 & 0.59 & 0.33 & 0.36 & 0.37 & 0.47 & 0.32 & 0.45 & 0.44 & 0.57 & 0.51 & 0.66 \\
\hline & 2 years before UE: Unemployed 1-6 months & 0.17 & 0.22 & 0.24 & 0.31 & 0.19 & 0.20 & 0.21 & 0.21 & 0.15 & 0.20 & 0.18 & 0.25 & 0.19 & 0.26 & 0.22 & 0.26 & 0.17 & 0.20 & 0.16 & 0.18 \\
\hline & 2 years before UE: Unemployed 7-12 months & 0.15 & 0.14 & 0.24 & 0.26 & 0.19 & 0.11 & 0.16 & 0.13 & 0.19 & 0.14 & 0.21 & 0.28 & 0.21 & 0.21 & 0.20 & 0.18 & 0.19 & 0.15 & 0.16 & 0.10 \\
\hline & 2 years before UE: Unemployed 13-18 months & 0.11 & 0.05 & 0.11 & 0.05 & 0.13 & 0.04 & 0.11 & 0.05 & 0.12 & 0.05 & 0.14 & 0.09 & 0.15 & 0.05 & 0.16 & 0.08 & 0.14 & 0.06 & 0.09 & 0.04 \\
\hline & 2 years before UE: Unemployed 19-24 months & 0.04 & 0.02 & 0.06 & 0.01 & 0.08 & 0.01 & 0.06 & 0.02 & 0.10 & 0.02 & 0.14 & 0.02 & 0.09 & 0.02 & 0.10 & 0.03 & 0.06 & 0.03 & 0.07 & 0.02 \\
\hline & 2 years before UE: Participation in program & 0.36 & 0.17 & 0.34 & 0.13 & 0.41 & 0.15 & 0.33 & 0.16 & 0.39 & 0.16 & 0.45 & 0.17 & 0.39 & 0.17 & 0.46 & 0.25 & 0.40 & 0.20 & 0.44 & 0.22 \\
\hline & 2 years before UE: Periods of sickness & 0.10 & 0.06 & 0.12 & 0.08 & 0.12 & 0.04 & 0.10 & 0.05 & 0.11 & 0.05 & 0.17 & 0.09 & 0.15 & 0.08 & 0.14 & 0.08 & 0.13 & 0.06 & 0.12 & 0.05 \\
\hline & 2 years before UE: Sanctioned & 0.01 & 0.01 & 0.01 & 0.00 & 0.01 & 0.00 & 0.01 & 0.01 & 0.01 & 0.01 & 0.01 & 0.01 & 0.01 & 0.01 & 0.03 & 0.02 & 0.01 & 0.01 & 0.00 & 0.01 \\
\hline
\end{tabular}

\#) UE = unemployment spell before taking up a job during the second quarter of 2003. 


\begin{tabular}{|c|c|c|c|c|c|c|c|c|c|c|c|c|c|c|c|c|c|c|c|c|c|}
\hline & & \multicolumn{2}{|c|}{$\begin{array}{l}\text { Metal } \\
\text { products }\end{array}$} & \multicolumn{2}{|c|}{ Construction } & \multicolumn{2}{|c|}{$\begin{array}{l}\text { Automobile } \\
\text { trade/repair }\end{array}$} & \multicolumn{2}{|c|}{ Wholesale } & \multicolumn{2}{|c|}{ Retail trade } & \multicolumn{2}{|c|}{$\begin{array}{l}\text { Hotels/ } \\
\text { restaurants }\end{array}$} & \multicolumn{2}{|c|}{$\begin{array}{c}\text { Land } \\
\text { transportation }\end{array}$} & \multicolumn{2}{|c|}{$\begin{array}{l}\text { Temporary } \\
\text { help firms }\end{array}$} & \multicolumn{2}{|c|}{$\begin{array}{l}\text { Other ec. } \\
\text { services }\end{array}$} & \multicolumn{2}{|c|}{$\begin{array}{l}\text { Health/soc. } \\
\text { services }\end{array}$} \\
\hline & & $\mathrm{S}$ & $\mathrm{U}$ & $\mathrm{S}$ & $\mathrm{U}$ & $\mathrm{S}$ & $\mathrm{U}$ & $\mathrm{S}$ & $\mathrm{U}$ & $\mathrm{S}$ & $\mathrm{U}$ & $\mathrm{S}$ & $\mathrm{U}$ & $\mathrm{S}$ & $\mathrm{U}$ & $\mathrm{S}$ & $\mathrm{U}$ & $\mathrm{S}$ & $\mathrm{U}$ & $\mathrm{S}$ & $\mathrm{U}$ \\
\hline \multirow{27}{*}{ 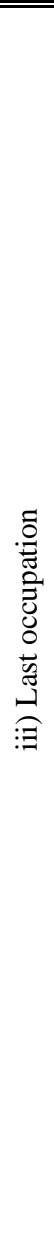 } & Agricultural worker & 0.02 & 0.01 & 0.01 & 0.01 & 0.01 & 0.01 & 0.02 & 0.01 & 0.04 & 0.04 & 0.04 & 0.01 & 0.01 & 0.01 & 0.02 & 0.02 & 0.03 & 0.02 & 0.02 & 0.01 \\
\hline & Miner/stone/ceramics worker & 0.00 & 0.00 & 0.01 & 0.00 & 0.00 & 0.00 & 0.01 & 0.01 & 0.00 & 0.00 & 0.00 & 0.00 & 0.00 & 0.00 & 0.00 & 0.00 & 0.00 & 0.00 & 0.00 & 0.00 \\
\hline & Chemistry worker & 0.01 & 0.01 & 0.00 & 0.00 & 0.01 & 0.01 & 0.01 & 0.01 & 0.01 & 0.00 & 0.00 & 0.00 & 0.01 & 0.00 & 0.01 & 0.02 & 0.01 & 0.01 & 0.00 & 0.00 \\
\hline & Paper/wood worker & 0.02 & 0.01 & 0.00 & 0.00 & 0.01 & 0.01 & 0.02 & 0.01 & 0.00 & 0.01 & 0.00 & 0.00 & 0.01 & 0.00 & 0.01 & 0.01 & 0.01 & 0.01 & 0.01 & 0.00 \\
\hline & Metal trade worker & 0.11 & 0.12 & 0.01 & 0.01 & 0.00 & 0.01 & 0.02 & 0.01 & 0.01 & 0.01 & 0.00 & 0.00 & 0.01 & 0.01 & 0.06 & 0.05 & 0.01 & 0.01 & 0.01 & 0.00 \\
\hline & Mechanic & 0.32 & 0.35 & 0.11 & 0.08 & 0.32 & 0.31 & 0.07 & 0.07 & 0.08 & 0.06 & 0.02 & 0.01 & 0.07 & 0.04 & 0.13 & 0.17 & 0.05 & 0.05 & 0.04 & 0.02 \\
\hline & Electrician & 0.04 & 0.02 & 0.04 & 0.03 & 0.02 & 0.03 & 0.03 & 0.03 & 0.04 & 0.03 & 0.01 & 0.00 & 0.01 & 0.01 & 0.07 & 0.07 & 0.02 & 0.02 & 0.01 & 0.01 \\
\hline & Assembly worker & 0.03 & 0.05 & 0.01 & 0.00 & 0.01 & 0.01 & 0.01 & 0.01 & 0.01 & 0.01 & 0.00 & 0.01 & 0.01 & 0.01 & 0.04 & 0.04 & 0.01 & 0.01 & 0.01 & 0.01 \\
\hline & Textile/leather worker & 0.00 & 0.00 & 0.00 & 0.00 & 0.00 & 0.00 & 0.00 & 0.01 & 0.01 & 0.01 & 0.01 & 0.00 & 0.00 & 0.00 & 0.01 & 0.01 & 0.00 & 0.00 & 0.02 & 0.00 \\
\hline & Food industry worker & 0.00 & 0.01 & 0.00 & 0.00 & 0.01 & 0.01 & 0.02 & 0.02 & 0.02 & 0.04 & 0.25 & 0.31 & 0.02 & 0.01 & 0.02 & 0.02 & 0.01 & 0.02 & 0.02 & 0.03 \\
\hline & Construction worker & 0.07 & 0.08 & 0.41 & 0.45 & 0.05 & 0.03 & 0.08 & 0.06 & 0.06 & 0.03 & 0.02 & 0.01 & 0.12 & 0.06 & 0.08 & 0.06 & 0.10 & 0.07 & 0.02 & 0.01 \\
\hline & Fitting worker & 0.03 & 0.02 & 0.10 & 0.10 & 0.01 & 0.01 & 0.02 & 0.02 & 0.03 & 0.02 & 0.00 & 0.00 & 0.02 & 0.01 & 0.02 & 0.02 & 0.02 & 0.02 & 0.00 & 0.00 \\
\hline & Carpenter & 0.03 & 0.03 & 0.05 & 0.03 & 0.02 & 0.01 & 0.05 & 0.02 & 0.04 & 0.03 & 0.01 & 0.00 & 0.05 & 0.01 & 0.03 & 0.02 & 0.01 & 0.01 & 0.02 & 0.01 \\
\hline & Painter & 0.03 & 0.02 & 0.06 & 0.13 & 0.04 & 0.05 & 0.02 & 0.01 & 0.02 & 0.02 & 0.01 & 0.00 & 0.01 & 0.01 & 0.05 & 0.07 & 0.02 & 0.02 & 0.01 & 0.01 \\
\hline & Shipment worker & 0.02 & 0.02 & 0.00 & 0.00 & 0.00 & 0.01 & 0.02 & 0.02 & 0.02 & 0.01 & 0.02 & 0.01 & 0.02 & 0.01 & 0.03 & 0.04 & 0.01 & 0.02 & 0.01 & 0.01 \\
\hline & Unskilled worker & 0.00 & 0.00 & 0.00 & 0.00 & 0.00 & 0.00 & 0.00 & 0.00 & 0.00 & 0.00 & 0.00 & 0.00 & 0.00 & 0.00 & 0.00 & 0.01 & 0.00 & 0.00 & 0.00 & 0.00 \\
\hline & Machine operator & 0.01 & 0.01 & 0.03 & 0.04 & 0.00 & 0.01 & 0.02 & 0.01 & 0.00 & 0.01 & 0.00 & 0.00 & 0.04 & 0.04 & 0.01 & 0.01 & 0.01 & 0.01 & 0.00 & 0.00 \\
\hline & Engineers & 0.02 & 0.02 & 0.02 & 0.01 & 0.00 & 0.01 & 0.01 & 0.02 & 0.00 & 0.01 & 0.00 & 0.00 & 0.01 & 0.01 & 0.01 & 0.01 & 0.08 & 0.06 & 0.01 & 0.01 \\
\hline & Technican & 0.03 & 0.03 & 0.02 & 0.01 & 0.00 & 0.01 & 0.02 & 0.02 & 0.01 & 0.01 & 0.00 & 0.00 & 0.01 & 0.01 & 0.01 & 0.01 & 0.03 & 0.03 & 0.01 & 0.00 \\
\hline & Sales worker & 0.01 & 0.01 & 0.00 & 0.00 & 0.00 & 0.00 & 0.01 & 0.00 & 0.01 & 0.00 & 0.00 & 0.00 & 0.00 & 0.00 & 0.00 & 0.01 & 0.04 & 0.02 & 0.00 & 0.00 \\
\hline & Service worker & 0.03 & 0.03 & 0.02 & 0.01 & 0.15 & 0.17 & 0.12 & 0.16 & 0.28 & 0.35 & 0.11 & 0.08 & 0.04 & 0.04 & 0.06 & 0.05 & 0.09 & 0.08 & 0.06 & 0.04 \\
\hline & Transportation worker & 0.07 & 0.06 & 0.04 & 0.03 & 0.09 & 0.09 & 0.16 & 0.21 & 0.06 & 0.09 & 0.03 & 0.03 & 0.44 & 0.63 & 0.12 & 0.12 & 0.07 & 0.07 & 0.03 & 0.02 \\
\hline & Clerical worker & 0.08 & 0.06 & 0.05 & 0.03 & 0.13 & 0.15 & 0.20 & 0.19 & 0.17 & 0.12 & 0.09 & 0.05 & 0.04 & 0.05 & 0.12 & 0.10 & 0.22 & 0.21 & 0.14 & 0.09 \\
\hline & Security services worker & 0.01 & 0.01 & 0.01 & 0.01 & 0.02 & 0.01 & 0.01 & 0.01 & 0.01 & 0.01 & 0.02 & 0.01 & 0.02 & 0.01 & 0.02 & 0.01 & 0.05 & 0.07 & 0.00 & 0.01 \\
\hline & Health/social/education worker & 0.00 & 0.01 & 0.00 & 0.00 & 0.02 & 0.02 & 0.01 & 0.03 & 0.03 & 0.04 & 0.02 & 0.02 & 0.02 & 0.01 & 0.02 & 0.02 & 0.03 & 0.04 & 0.48 & 0.66 \\
\hline & General services worker & 0.01 & 0.01 & 0.01 & 0.00 & 0.03 & 0.03 & 0.02 & 0.02 & 0.03 & 0.04 & 0.32 & 0.41 & 0.01 & 0.01 & 0.04 & 0.03 & 0.04 & 0.09 & 0.06 & 0.05 \\
\hline & Other worker & 0.00 & 0.01 & 0.00 & 0.00 & 0.00 & 0.00 & 0.01 & 0.01 & 0.01 & 0.01 & 0.01 & 0.01 & 0.01 & 0.01 & 0.01 & 0.01 & 0.02 & 0.02 & 0.01 & 0.01 \\
\hline
\end{tabular}




\begin{tabular}{|c|c|c|c|c|c|c|c|c|c|c|c|c|c|c|c|c|c|c|c|c|c|}
\hline & & \multicolumn{2}{|c|}{$\begin{array}{c}\text { Metal } \\
\text { products }\end{array}$} & \multicolumn{2}{|c|}{ Construction } & \multicolumn{2}{|c|}{$\begin{array}{l}\text { Automobile } \\
\text { trade/repair }\end{array}$} & \multicolumn{2}{|c|}{ Wholesale } & \multicolumn{2}{|c|}{ Retail trade } & \multicolumn{2}{|c|}{$\begin{array}{l}\text { Hotels/ } \\
\text { restaurants }\end{array}$} & \multicolumn{2}{|c|}{$\begin{array}{c}\text { Land } \\
\text { transportation }\end{array}$} & \multicolumn{2}{|c|}{$\begin{array}{l}\text { Temporary } \\
\text { help firms }\end{array}$} & \multicolumn{2}{|c|}{$\begin{array}{l}\text { Other ec. } \\
\text { services }\end{array}$} & \multicolumn{2}{|c|}{$\begin{array}{c}\text { Health/soc. } \\
\text { services }\end{array}$} \\
\hline & & $\mathrm{S}$ & $\mathrm{U}$ & $\mathrm{S}$ & $\mathrm{U}$ & $\mathrm{S}$ & $\mathrm{U}$ & $\mathrm{S}$ & $\mathrm{U}$ & $\mathrm{S}$ & $\mathrm{U}$ & $\mathrm{S}$ & $\mathrm{U}$ & $\mathrm{S}$ & $\mathrm{U}$ & $\mathrm{S}$ & $\mathrm{U}$ & $\mathrm{S}$ & $\mathrm{U}$ & $\mathrm{S}$ & $\mathrm{U}$ \\
\hline \multirow{11}{*}{ 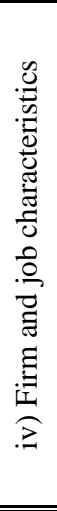 } & Firm size $<10$ & 0.33 & 0.28 & 0.52 & 0.49 & 0.50 & 0.42 & 0.41 & 0.27 & 0.62 & 0.48 & 0.68 & 0.55 & 0.51 & 0.42 & 0.06 & 0.03 & 0.51 & 0.32 & 0.44 & 0.26 \\
\hline & Firm size $10-24$ & 0.25 & 0.24 & 0.28 & 0.29 & 0.3 & 0.26 & 0.25 & 0.23 & 0.19 & 0.21 & 0.17 & 0.24 & 0.26 & 0.29 & 0.15 & 0.09 & 0.20 & 0.19 & 0.21 & 0.15 \\
\hline & Firm size $25-74$ & 0.27 & 0.23 & 0.14 & 0.16 & 0.15 & 0.20 & 0.22 & 0.26 & 0.14 & 0.15 & 0.13 & 0.16 & 0.16 & 0.19 & 0.40 & 0.40 & 0.17 & 0.19 & 0.20 & 0.24 \\
\hline & $\underline{\text { Firm size }>=75}$ & 0.14 & 0.25 & 0.05 & 0.07 & 0.04 & 0.12 & 0.12 & 0.24 & 0.05 & 0.16 & 0.02 & 0.06 & 0.08 & 0.10 & 0.38 & 0.49 & 0.11 & 0.30 & 0.14 & 0.36 \\
\hline & Mean daily wage in firm: Percentile 1-25 & 0.13 & 0.10 & 0.19 & 0.17 & 0.26 & 0.19 & 0.20 & 0.09 & 0.41 & 0.28 & 0.74 & 0.55 & 0.25 & 0.17 & 0.34 & 0.35 & 0.39 & 0.27 & 0.29 & 0.14 \\
\hline & Mean daily wage in firm: Percentile $26-50$ & 0.31 & 0.15 & 0.28 & 0.18 & 0.37 & 0.18 & 0.22 & 0.12 & 0.25 & 0.24 & 0.22 & 0.29 & 0.35 & 0.23 & 0.48 & 0.45 & 0.24 & 0.22 & 0.33 & 0.23 \\
\hline & Mean daily wage in firm: Percentile 51-75 & 0.34 & 0.27 & 0.35 & 0.31 & 0.23 & 0.28 & 0.29 & 0.25 & 0.25 & 0.28 & 0.03 & 0.13 & 0.28 & 0.32 & 0.15 & 0.17 & 0.18 & 0.20 & 0.24 & 0.32 \\
\hline & Mean daily wage in firm: Percentile 76-100 & 0.23 & 0.48 & 0.19 & 0.34 & 0.14 & 0.35 & 0.29 & 0.54 & 0.09 & 0.20 & 0.01 & 0.03 & 0.13 & 0.28 & 0.03 & 0.03 & 0.19 & 0.31 & 0.14 & 0.31 \\
\hline & Unqualified blue collar worker & 0.34 & 0.39 & 0.24 & 0.26 & 0.19 & 0.25 & 0.29 & 0.37 & 0.20 & 0.22 & 0.37 & 0.48 & 0.38 & 0.50 & 0.51 & 0.54 & 0.27 & 0.38 & 0.13 & 0.15 \\
\hline & Qualified blue collar worker & 0.55 & 0.50 & 0.66 & 0.69 & 0.52 & 0.42 & 0.34 & 0.21 & 0.28 & 0.22 & 0.48 & 0.42 & 0.53 & 0.44 & 0.31 & 0.33 & 0.21 & 0.16 & 0.14 & 0.07 \\
\hline & White collar worker & 0.11 & 0.11 & 0.10 & 0.05 & 0.28 & 0.33 & 0.38 & 0.43 & 0.52 & 0.57 & 0.15 & 0.10 & 0.09 & 0.06 & 0.18 & 0.13 & 0.52 & 0.46 & 0.73 & 0.78 \\
\hline \multirow{12}{*}{ 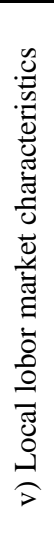 } & East Germany, worst situation & 0.07 & 0.04 & 0.11 & 0.06 & 0.11 & 0.03 & 0.08 & 0.03 & & 0.03 & 0.13 & 0.04 & 0.13 & 0.04 & 0.06 & 0.04 & 0.07 & 0.03 & 0.07 & 0.02 \\
\hline & East Germany, bad situation & 0.39 & 0.21 & 0.48 & 0.26 & 0.35 & 0.13 & 0.34 & 0.13 & 0.31 & 0.15 & 0.44 & 0.25 & 0.37 & 0.21 & 0.21 & 0.18 & 0.36 & 0.18 & 0.37 & 0.11 \\
\hline & East Germany, high unemployment & 0.13 & 0.05 & 0.10 & 0.07 & 0.08 & 0.04 & 0.06 & 0.04 & 0.10 & 0.04 & 0.12 & 0.04 & 0.08 & 0.06 & 0.06 & 0.05 & 0.08 & 0.04 & 0.07 & 0.03 \\
\hline & Urban area, high unemployment & 0.03 & 0.04 & 0.04 & 0.05 & 0.03 & 0.07 & 0.05 & 0.06 & 0.07 & 0.07 & 0.04 & 0.06 & 0.07 & 0.06 & 0.07 & 0.07 & 0.07 & 0.10 & 0.07 & 0.10 \\
\hline & Urban area, medium unemployment & 0.06 & 0.10 & 0.04 & 0.05 & 0.08 & 0.12 & 0.11 & 0.13 & 0.08 & 0.11 & 0.04 & 0.06 & 0.05 & 0.08 & 0.20 & 0.14 & 0.09 & 0.13 & 0.08 & 0.13 \\
\hline & Above average unemp., moderate dynamics & 0.05 & 0.06 & 0.04 & 0.07 & 0.08 & 0.07 & 0.06 & 0.06 & 0.08 & 0.09 & 0.05 & 0.13 & 0.05 & 0.06 & 0.05 & 0.05 & 0.06 & 0.05 & 0.09 & 0.10 \\
\hline & Rural area, average unemployment & 0.03 & 0.06 & 0.04 & 0.06 & 0.06 & 0.07 & 0.05 & 0.06 & 0.05 & 0.07 & 0.03 & 0.05 & 0.07 & 0.07 & 0.06 & 0.05 & 0.04 & 0.05 & 0.06 & 0.07 \\
\hline & Rural area, below average unemployment & 0.12 & 0.17 & 0.08 & 0.12 & 0.09 & 0.18 & 0.13 & 0.17 & 0.11 & 0.14 & 0.05 & 0.10 & 0.09 & 0.14 & 0.14 & 0.13 & 0.10 & 0.12 & 0.09 & 0.15 \\
\hline & Center, good situation and high dynamics & 0.01 & 0.04 & 0.01 & 0.04 & 0.03 & 0.08 & 0.03 & 0.11 & 0.05 & 0.09 & 0.01 & 0.07 & 0.03 & 0.06 & 0.04 & 0.10 & 0.04 & 0.12 & 0.03 & 0.09 \\
\hline & Rural area, good situation and high dynamics & 0.02 & 0.04 & 0.01 & 0.09 & 0.01 & 0.04 & 0.01 & 0.04 & 0.02 & 0.04 & 0.01 & 0.05 & 0.03 & 0.05 & 0.02 & 0.03 & 0.01 & 0.02 & 0.02 & 0.03 \\
\hline & Small-business dominated, good situation & 0.05 & 0.12 & 0.02 & 0.06 & 0.05 & 0.11 & 0.05 & 0.12 & 0.03 & 0.10 & 0.03 & 0.09 & 0.02 & 0.10 & 0.05 & 0.11 & 0.04 & 0.10 & 0.03 & 0.10 \\
\hline & Very good situation & 0.04 & 0.07 & 0.02 & 0.07 & 0.03 & 0.06 & 0.04 & 0.06 & 0.04 & 0.06 & 0.03 & 0.08 & 0.02 & 0.07 & 0.03 & 0.05 & 0.04 & 0.05 & 0.03 & 0.06 \\
\hline
\end{tabular}




\begin{tabular}{|c|c|c|c|c|c|c|c|c|c|c|c|c|c|c|c|c|c|c|c|c|c|}
\hline & & \multicolumn{2}{|c|}{$\begin{array}{c}\text { Metal } \\
\text { products }\end{array}$} & \multicolumn{2}{|c|}{ Construction } & \multicolumn{2}{|c|}{$\begin{array}{l}\text { Automobile } \\
\text { trade/repair }\end{array}$} & \multicolumn{2}{|c|}{ Wholesale } & \multicolumn{2}{|c|}{ Retail trade } & \multicolumn{2}{|c|}{$\begin{array}{l}\text { Hotels/ } \\
\text { restaurants }\end{array}$} & \multicolumn{2}{|c|}{$\begin{array}{c}\text { Land } \\
\text { transportation }\end{array}$} & \multicolumn{2}{|c|}{$\begin{array}{l}\text { Temporary } \\
\text { help firms }\end{array}$} & \multicolumn{2}{|c|}{$\begin{array}{l}\text { Other ec. } \\
\text { services }\end{array}$} & \multicolumn{2}{|c|}{$\begin{array}{c}\text { Health/soc. } \\
\text { services }\end{array}$} \\
\hline & & $\mathrm{S}$ & $\mathrm{U}$ & $\mathrm{S}$ & $\mathrm{U}$ & $\mathrm{S}$ & $\mathrm{U}$ & $\mathrm{S}$ & $\mathrm{U}$ & $\mathrm{S}$ & $\mathrm{U}$ & $\mathrm{S}$ & $\mathrm{U}$ & $\mathrm{S}$ & $\mathrm{U}$ & $\mathrm{S}$ & $\mathrm{U}$ & $\mathrm{S}$ & $\mathrm{U}$ & $\mathrm{S}$ & $\mathrm{U}$ \\
\hline \multirow{20}{*}{ 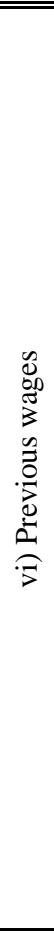 } & Latest daily Wage: Percentile 0-10 & 0.14 & 0.07 & 0.09 & 0.04 & 0.15 & 0.10 & 0.15 & 0.09 & 0.22 & 0.12 & 0.29 & 0.14 & 0.13 & 0.07 & 0.19 & 0.12 & 0.20 & 0.14 & 0.33 & 0.20 \\
\hline & Latest daily Wage: Percentile 11-20 & 0.08 & 0.05 & 0.06 & 0.03 & 0.12 & 0.07 & 0.10 & 0.06 & 0.17 & 0.13 & 0.26 & 0.26 & 0.10 & 0.06 & 0.15 & 0.14 & 0.13 & 0.12 & 0.14 & 0.12 \\
\hline & Latest daily Wage: Percentile 21-30 & 0.10 & 0.08 & 0.10 & 0.05 & 0.14 & 0.08 & 0.10 & 0.08 & 0.14 & 0.11 & 0.18 & 0.20 & 0.14 & 0.10 & 0.13 & 0.14 & 0.14 & 0.11 & 0.14 & 0.09 \\
\hline & Latest daily Wage: Percentile 31-40 & 0.15 & 0.10 & 0.16 & 0.09 & 0.11 & 0.08 & 0.12 & 0.08 & 0.07 & 0.10 & 0.10 & 0.11 & 0.16 & 0.11 & 0.13 & 0.12 & 0.10 & 0.09 & 0.09 & 0.08 \\
\hline & Latest daily Wage: Percentile 41-50 & 0.10 & 0.10 & 0.15 & 0.12 & 0.12 & 0.09 & 0.08 & 0.08 & 0.07 & 0.08 & 0.07 & 0.08 & 0.11 & 0.10 & 0.09 & 0.10 & 0.09 & 0.08 & 0.05 & 0.07 \\
\hline & Latest daily Wage: Percentile 51-60 & 0.08 & 0.11 & 0.13 & 0.11 & 0.12 & 0.11 & 0.12 & 0.10 & 0.07 & 0.09 & 0.03 & 0.06 & 0.11 & 0.13 & 0.09 & 0.10 & 0.07 & 0.08 & 0.08 & 0.08 \\
\hline & Latest daily Wage: Percentile $61-70$ & 0.12 & 0.12 & 0.10 & 0.12 & 0.07 & 0.13 & 0. & 0.12 & 07 & 0.10 & 0.04 & 0.06 & 0.09 & 0.14 & 0.09 & 0.08 & 0.06 & 0.08 & 0.05 & 0.08 \\
\hline & Latest daily Wage: Percentile 71-80 & 0.08 & 0.12 & 0.08 & 0.15 & 0.05 & 0.11 & 0.07 & 0.10 & 0.08 & 0.09 & 0.02 & 0.03 & 0.07 & 0.12 & 0.07 & 0.07 & 0.06 & 0.07 & 0.04 & 0.08 \\
\hline & Latest daily Wage: Percentile 81-90 & 0.07 & 0.12 & 0.07 & 0.16 & 0.06 & 0.11 & 0.08 & 0.10 & 0.05 & 0.07 & 0.01 & 0.03 & 0.06 & 0.09 & 0.03 & 0.06 & 0.05 & 0.08 & 0.03 & 0.08 \\
\hline & Latest daily Wage: Percentile 91-100 & 0.09 & 0.13 & 0.07 & 0.12 & 0.06 & 0.13 & 0.09 & 0.18 & 0.05 & 0.10 & 0.01 & 0.03 & 0.05 & 0.08 & 0.04 & 0.06 & 0.09 & 0.15 & 0.04 & 0.11 \\
\hline & Previous cumulated wages: Percentile 0-10 & 0.17 & 0.07 & 0.11 & 0.04 & 0.20 & 0.09 & & 0.09 & & & 0.36 & 0.11 & 0.17 & 0.06 & 0.26 & & 0.25 & 0.14 & 0.34 & \\
\hline & Previous cumulated wages: Percentile 11-20 & 0.13 & 0.07 & 0.11 & 0.05 & 0.16 & 0.07 & 0.12 & 0.09 & 0.15 & 0.11 & 0.22 & 0.19 & 0.14 & 0.08 & 0.19 & 0.14 & 0.17 & 0.11 & 0.19 & 0.11 \\
\hline & Previous cumulated wages: Percentile 21-30 & 0.10 & 0.07 & 0.11 & 0.06 & 0.11 & 0.07 & 0.10 & 0.07 & 0.14 & 0.11 & 0.19 & 0.21 & 0.13 & 0.09 & 0.15 & 0.12 & 0.10 & 0.10 & 0.11 & 0.10 \\
\hline & Previous cumulated wages: Percentile 31-40 & 0.08 & 0.08 & 0.12 & 0.08 & 0.09 & 0.08 & 0.08 & 0.08 & 0.11 & 0.10 & 0.08 & 0.16 & 0.12 & 0.09 & 0.10 & 0.12 & 0.09 & 0.10 & 0.08 & 0.11 \\
\hline & Previous cumulated wages: Percentile 41-50 & 0.08 & 0.09 & 0.14 & 0.11 & 0.10 & 0.10 & 0.09 & 0.08 & 0.09 & 0.09 & 0.05 & 0.11 & 0.12 & 0.11 & 0.07 & 0.11 & 0.09 & 0.09 & 0.07 & 0.08 \\
\hline & Previous cumulated wages: Percentile 51-60 & 0.10 & 0.10 & 0.12 & 0.12 & 0.11 & 0.09 & 0.09 & 0.09 & 0.07 & 0.09 & 0.03 & 0.08 & 0.09 & 0.12 & 0.07 & 0.10 & 0.08 & 0.08 & 0.06 & 0.07 \\
\hline & Previous cumulated wages: Percentile 61-70 & 0.10 & 0.11 & 0.09 & 0.14 & 0.07 & 0.09 & 0.09 & 0.09 & 0.06 & 0.09 & 0.04 & 0.06 & 0.08 & 0.12 & 0.06 & 0.08 & 0.08 & 0.07 & 0.04 & 0.07 \\
\hline & Previous cumulated wages: Percentile 71-80 & 0.06 & 0.11 & 0.08 & 0.15 & 0.07 & 0.10 & 0.09 & 0.10 & 0.06 & 0.09 & 0.02 & 0.04 & 0.05 & 0.13 & 0.05 & 0.07 & 0.04 & 0.08 & 0.04 & 0.08 \\
\hline & Previous cumulated wages: Percentile 81-90 & 0.08 & 0.13 & 0.07 & 0.14 & 0.04 & 0.14 & 0.09 & 0.12 & 0.04 & 0.10 & 0.01 & 0.03 & 0.07 & 0.12 & 0.04 & 0.06 & 0.04 & 0.08 & 0.04 & 0.08 \\
\hline & Previous cumulated wages: Percentile 91-100 & 0.09 & 0.17 & 0.05 & 0.11 & 0.04 & 0.18 & 0.06 & 0.19 & 0.04 & 0.11 & 0.00 & 0.02 & 0.04 & 0.09 & 0.02 & 0.06 & 0.06 & 0.15 & 0.03 & 0.10 \\
\hline \multirow{8}{*}{ 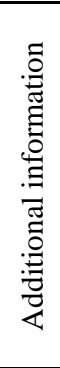 } & " Average duration of subsidy (in days) & 134 & (- & 135 & $\begin{array}{l}- \\
-\end{array}$ & 154 & - & 142 & (- & 154 & (- & 162 & (- & 155 & (- & 125 & $\begin{array}{l}- \\
\end{array}$ & 151 & (- & 157 & 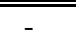 \\
\hline & Average daily subsidy rate (in Euro) & 17.5 & - & 17.3 & - & 17.8 & - & 18.1 & - & 18.4 & - & 18.3 & - & 18.5 & - & 19.6 & - & 18.3 & - & 17.9 & - \\
\hline & Average costs of subsidy (in Euro) & 2438 & - & 2438 & - & 2826 & - & 2626 & - & 2903 & - & 3050 & - & 2925 & - & 2456 & - & 2825 & - & 2934 & - \\
\hline & Daily unemployment benefits (in Euro) & 18.6 & 22.0 & 19.6 & 23.4 & 18.1 & 21.0 & 18.1 & 22.0 & 16.5 & 18.6 & 13.5 & 15.9 & 17.9 & 20.4 & 16.0 & 16.4 & 17.3 & 19.3 & 15.3 & 17.2 \\
\hline & Number of observations & 459 & 4694 & 1962 & 42316 & 404 & 2987 & 586 & 7295 & 665 & 8136 & 446 & 12443 & 400 & 5248 & 627 & 22181 & 951 & 12107 & 448 & 7668 \\
\hline & $\underline{\text { Hired persons per firm }}$ & 1.9 & 3.7 & 2.1 & 2.9 & 1.2 & 1.6 & 2.1 & 2.2 & 1.4 & 2.0 & 1.6 & 2.3 & 2.0 & 2.1 & 7.9 & 11.3 & 2.0 & 4.5 & 1.4 & 1.9 \\
\hline & At least one other industry within 3.5 years & 0.09 & 0.25 & 0.06 & 0.13 & 0.07 & 0.18 & 0.08 & 0.26 & 0.08 & 0.20 & 0.06 & 0.14 & 0.10 & 0.25 & 0.14 & 0.30 & 0.06 & 0.22 & 0.03 & 0.10 \\
\hline & Hiring occupation not equal latest occupation & 0.65 & 0.53 & 0.40 & 0.28 & 0.54 & 0.46 & 0.63 & 0.54 & 0.53 & 0.45 & 0.54 & 0.39 & 0.54 & 0.34 & 0.63 & 0.61 & 0.58 & 0.55 & 0.40 & 0.27 \\
\hline
\end{tabular}


Table A.2: $\quad$ Fiscal cost-benefit analysis of direct within industry program effects for the 3.5 year period since taking up the job (mean values in Euro)

\begin{tabular}{|c|c|c|c|c|c|c|c|c|c|c|}
\hline & $\begin{array}{c}\text { Metal } \\
\text { products }\end{array}$ & Constr. & $\begin{array}{c}\text { Autom. } \\
\text { trade/repair }\end{array}$ & $\begin{array}{c}\text { Whole- } \\
\text { sale }\end{array}$ & Retail trade & $\begin{array}{c}\text { Hotels/ } \\
\text { restaurants }\end{array}$ & $\begin{array}{l}\text { Land } \\
\text { transp. }\end{array}$ & $\begin{array}{l}\text { Temporary } \\
\text { help firms }\end{array}$ & $\begin{array}{l}\text { Other ec. } \\
\text { services }\end{array}$ & $\begin{array}{c}\text { Health/soc. } \\
\text { services }\end{array}$ \\
\hline Daily unemployment benefit/assistance (in Euro) & 19 & 20 & 18 & 18 & 17 & 14 & 18 & 16 & 17 & 15 \\
\hline Additional days in employment & 99 & 93 & 89 & 98 & 61 & 125 & 85 & 65 & 105 & 85 \\
\hline A) Savings in unemployment benefits/assistance & 1834 & 1832 & 1609 & 1783 & 1004 & 1688 & 1523 & 1045 & 1817 & 1299 \\
\hline Additional earnings over 3.5 years (in Euro) & 3599 & 4793 & 3241 & 4177 & 2544 & 4927 & 2848 & 2999 & 4948 & 1961 \\
\hline B) Additional social sec. contributions/taxes & 1800 & 2396 & 1620 & 2088 & 1272 & 2464 & 1424 & 1499 & 2474 & 980 \\
\hline Duration of the subsidy (in days) & 134 & 135 & 154 & 142 & 154 & 162 & 155 & 125 & 151 & 157 \\
\hline Daily rate of subsidization (in Euro) & 17 & 17 & 18 & 18 & 18 & 18 & 18 & 20 & 18 & 18 \\
\hline C) Amount of the subsidy (in Euro) & 2438 & 2438 & 2826 & 2626 & 2903 & 3050 & 2925 & 2456 & 2825 & 2934 \\
\hline$A+B-C=$ Fiscal net effect (in Euro) & 1195 & 1791 & 403 & 1246 & -626 & 1101 & 21 & 88 & 1466 & -655 \\
\hline
\end{tabular}

Note: The analysis is based on estimation results from Table 3 and on means from Table A.1. For A), B), and A+B-C, bold types indicate significance at $\alpha=0.05$. 
Table A.3: $\quad$ Sectoral composition of the comparison group in Table 4 (shares)

\begin{tabular}{|c|c|c|c|c|c|c|c|c|c|c|}
\hline \multirow[b]{2}{*}{$\begin{array}{l}\text { Composition } \\
\text { comparison group }\end{array}$} & \multicolumn{10}{|c|}{ Treatment group } \\
\hline & $\begin{array}{c}\text { Metal } \\
\text { products }\end{array}$ & Construction & $\begin{array}{l}\text { Automobile } \\
\text { trade/repair }\end{array}$ & Wholesale & Retail trade & $\begin{array}{c}\text { Hotels/ } \\
\text { restaurants }\end{array}$ & $\begin{array}{c}\text { Land } \\
\text { transportation }\end{array}$ & $\begin{array}{l}\text { Temporary } \\
\text { help firms }\end{array}$ & $\begin{array}{l}\text { Other ec. } \\
\text { services }\end{array}$ & $\begin{array}{c}\text { Health/soc. } \\
\text { services }\end{array}$ \\
\hline Metal products & - & 0.14 & 0.10 & 0.08 & 0.05 & 0.02 & 0.07 & 0.12 & 0.07 & 0.05 \\
\hline Construction & 0.35 & - & 0.29 & 0.26 & 0.20 & 0.10 & 0.31 & 0.14 & 0.25 & 0.12 \\
\hline Automobile trade & 0.09 & 0.11 & - & 0.07 & 0.08 & 0.08 & 0.08 & 0.05 & 0.06 & 0.06 \\
\hline Wholesale & 0.12 & 0.15 & 0.11 & - & 0.12 & 0.08 & 0.14 & 0.09 & 0.14 & 0.09 \\
\hline Retail trade & 0.07 & 0.13 & 0.12 & 0.12 & - & 0.24 & 0.09 & 0.09 & 0.14 & 0.21 \\
\hline Hotels \& restaurants & 0.02 & 0.03 & 0.05 & 0.04 & 0.10 & - & 0.04 & 0.07 & 0.08 & 0.10 \\
\hline Land transportation & 0.06 & 0.12 & 0.07 & 0.09 & 0.06 & 0.05 & - & 0.07 & 0.06 & 0.05 \\
\hline Temporay help firms & 0.15 & 0.07 & 0.09 & 0.09 & 0.08 & 0.10 & 0.10 & - & 0.12 & 0.11 \\
\hline Other economic services & 0.11 & 0.23 & 0.14 & 0.19 & 0.21 & 0.19 & 0.14 & 0.29 & - & 0.22 \\
\hline Health \& social services & 0.04 & 0.02 & 0.04 & 0.06 & 0.11 & 0.13 & 0.03 & 0.07 & 0.08 & - \\
\hline
\end{tabular}


Table A.4: Fiscal cost-benefit analysis of subsidization within one particular sector compared to subsidization within one of the other 9 industries for the 3.5 year period since taking up the job (mean values in Euro)

\begin{tabular}{|c|c|c|c|c|c|c|c|c|c|c|}
\hline & $\begin{array}{c}\text { Metal } \\
\text { products }\end{array}$ & Constr. & $\begin{array}{c}\text { Autom. } \\
\text { trade/repair }\end{array}$ & $\begin{array}{c}\text { Whole- } \\
\text { Sale }\end{array}$ & Retail trade & $\begin{array}{c}\text { Hotels/ } \\
\text { restaurants }\end{array}$ & $\begin{array}{l}\text { Land } \\
\text { transp. }\end{array}$ & $\begin{array}{l}\text { Temporary } \\
\text { help firms }\end{array}$ & $\begin{array}{l}\text { Other ec. } \\
\text { services }\end{array}$ & $\begin{array}{c}\text { Health/soc. } \\
\text { services }\end{array}$ \\
\hline Daily unemployment benefit/assistance (in Euro) & 19 & 20 & 18 & 18 & 17 & 14 & 18 & 16 & 17 & 15 \\
\hline Additional days in employment & 44 & -75 & 51 & 25 & -2 & -38 & 84 & -88 & 23 & 78 \\
\hline A) Savings in unemployment benefits/assistance & 820 & -1473 & 921 & 453 & -31 & -516 & 1495 & -1405 & 405 & 1186 \\
\hline Additional earnings over 3.5 years (in Euro) & 2449 & -2305 & 3037 & 1706 & -801 & -1914 & 2287 & -3732 & 1058 & 498 \\
\hline B) Additional social sec. contributions/taxes & 1225 & -1152 & 1519 & 853 & -400 & -957 & 1143 & -1866 & 529 & 249 \\
\hline$A+B=$ Fiscal net effect (in Euro) & 2045 & -2625 & 2439 & 1305 & -431 & -1473 & 2638 & -3271 & 935 & 1435 \\
\hline
\end{tabular}

Note: The analysis is based on estimation results from Table 4 and on means from Table A.1. For A), B) and A+B, bold types indicate significance at $\alpha=0.05$. 